\title{
Alteraciones en el cauce del río Seco y pérdidas de tierras agrícolas, provincia de Tucumán, Argentina
}

\author{
Alterations in the Seco river bed and losses of agricultural land,province of \\ Tucumán, Argentina
}

Mario Arnaldo Toledo ${ }^{1, *}$, Ana Lía Ahumada ${ }^{1,2}$, Gloria Patricia Ibañez Palacios ${ }^{1}$

${ }^{1}$ Instituto de Geología de Cuaternario y Paleoclimas, Fundación Miguel Lillo. Miguel Lillo 251, 4000, San Miguel de Tucumán, Tucumán, Argentina.

${ }^{2}$ CONICET- IGCYP-FML. Miguel Lillo 251, 4000, San Miguel de Tucumán, Tucumán, Argentina.

* Corresponding author: (M. A. Toledo) matoledo@lillo.org.ar

\section{RESUMEN}

La provincia de Tucumán, Argentina, presenta una densa red fluvial, con ríos que han manifestado, en los últimos 45 años, comportamientos complejos y dinámicos a consecuencia de los elevados caudales que les son aportados por sus cuencas superiores. En estas cuencas, ubicadas en la zona montañosa y pedemontana, se desarrollan diversas actividades antrópicas en relieves contrastados, con pendientes erosivas. El incremento de las precipitaciones registrado en la región a partir del año 1970 ha acrecentado los procesos erosivos y deposicionales en la llanura aluvial, modificando el diseño de los cauces, con importantes consecuencias sobre los campos de cultivo. Se analiza el cauce del río Seco, el cual tiene sus nacientes en la ladera oriental de la Sierra del Aconquija, recorre el piedemonte y la llanura aluvial en sentido Oeste-Este, hasta desaguar en el río Salí; cauce principal del sistema hídrico de la provincia. El principal objetivo de este trabajo fue realizar el análisis morfológico de los meandros en un tramo de su cauce, de aproximadamente 6.28 $\mathrm{km}$ de longitud, para el lapso temporal 1972 - 2017. Se analizó: la sinuosidad del cauce y los procesos de cortes de meandros por desborde (chute cutoff) y por tangencia (neck cutoff). Estos procesos han generado la pérdida acelerada de tierras agrícolas por erosión lateral de las barrancas del río, compuestas por sedimentos fluvio-aluviales, materiales parentales de los suelos productivos de la llanura aluvial. Previamente, se resaltan las características generales de la cuenca del río Seco, considerando la geología, geomorfología, clima, suelos y actividades antrópicas. También las características específicas de la subcuenca que

\section{ABSTRACT}

The province of Tucuman, Argentina has a dense fluvial network, with rivers that have shown, over the last 45 years, complex and dynamic behaviors, as a result of high streamflowes. In the upper basins, located in the mountainous zone and piedmont, diverse anthropic activities developed in contrasted reliefs and erosive slopes. The increase in rainfall recorded in the region since 1970 has increased both the erosive and depositional processes in the alluvial plain by modifying the design of the channels, with important consequences on the farmlands. In this paper, the Seco river bed is analyzed thoroughly. The Seco river is born on the eastern slope of the Aconquïa mountains, runs through the piedmont and the alluvial plain in a west-east direction, and finally discharges into the Sali river, the main river bed of the fluvial network of the province. The main objective of this work is an analysis of meander morphology along $6.28 \mathrm{~km}$ of the Seco river for the period 1972 to 2017. The main parameters analyzed were the sinuosity of the channel, and meander cuts by overflow (chute cutoff) and by tangency (neck cutoff). These processes have accelerated the loss of agricultural land by lateral erosion on the river ravines, which are composed of fluvial-alluvial sediments, the parental materials of the productive soils of alluvial plains. To begin our study, the general characteristics of the Seco river basin have been considered, including geology, geomorphology, climate, soils, and anthropic activities. In addition, specific features of the sub-basin that contributes its waters to the meander section were also taken into account: the increase of the flows due to the change toward the use of surrounding soils, the slopes of the field, the geomorphological region and morphometry. Landsat and Sentinel satellite images, as well as the SRTM Digital Elevation Model (DEM), were used for mapping the channel and crops. The resulting maps are basin and sub-basin watershed contribution to the meanders, slopes, elevation 
aporta sus aguas al tramo meandriforme, principalmente: el incremento de los caudales por el cambio de uso de los suelos, las pendientes del terreno, la región geomorfológica y la morfometría. Para el mapeo del cauce y de los cultivos se emplearon imágenes satelitales Landsat y Sentinel, y con el Modelo de Elevación Digital SRTM se elaboraron los mapas de: divisorias de aguas de la cuenca y de la subcuenca de aporte a los meandros, pendientes, curvas de nivel y red de drenaje. Los resultados muestran que la sinuosidad del cauce se incrementó en el lapso temporal 1972 -2002, tuvo una notable disminución en el lapso temporal 2002-2011 por los procesos de corte de meandros, incrementándose nuevamente en el lapso temporal 2011-2017, conjuntamente con la migración del cauce hacia el cuadrante sur. Estos cambios produjeron la pérdida de 370.68 ha de suelos productivos, lo que constituye $7.41 \mathrm{hm}^{3}$ de sedimentos removidos y transportados por la corriente. Los meandros del río Seco reflejan la degradación de la subcuenca de aporte, representando la situación de las cuencas del Noroeste Argentino, en las cuales el incremento en la intensidad y frecuencia de las precipitaciones a partir del año 1970 han generado condiciones críticas, cuyos efectos son más evidentes en las áreas bajas.

Palabras clave: río Seco, meandros, imágenes satelitales, uso del suelo, precipitaciones, Argentina. curves, and drainage network. The results show that the sinuosity of the channel increased in the period 1972-2002, had a notable decrease in the period 2002-2011 due to the processes of meander cuts, and increased again in the period 2011-2017, together with the migration of the channel towards the southern quadrant. These changes resulted in the loss of $370.68 \mathrm{ha}$ of productive soils, which represents $7.41 \mathrm{hm}^{3}$ of sediments removed and transported by the current. The meanders of the Seco river reflect the degradation of its area of contribution, representing the situation of the basins of the Argentine Northwest, in which the increase in the intensity and frequency of the precipitations since 1970 have generated critical conditions, whose effects are more evident in low areas.

Keywords: Seco river, meander, satellite image, land use, rainfall, Argentina.

\section{Introducción}

Debido a la energía que es suministrada por la cuenca durante las crecidas, los sistemas fluviales deben ajustar permanentemente la morfología de los cauces en el espacio y en el tiempo, lo que se traduce en movilidad lateral y vertical (Werritty, 1997). La morfología de los ríos aluviales se ve afectada por varios procesos interrelacionados que contribuyen a moldear el lecho del río, su configuración de forma plana y la estructura sedimentaria de la llanura aluvial circundante (Howard, 1996; Toonen et al., 2012; Van de Lageweg et al., 2016).

Los meandros son los principales responsables de la construcción y evolución de la llanura aluvial en los tramos bajos fluviales (García Lorenzo et al., 2015), mientras que los procesos de erosión y sedimentación, desarrollados en los arcos y sectores de inflexión de los meandros, controlan la forma del cauce y la dinámica morfológica y sedimentaria de la llanura de inundación adyacente (Hooke, 2007).

Asimismo, el contraste topográfico y sedimentario de las planicies aluviales (Ielpi y Ghinassi, 2014) ejerce un fuerte control sobre la erosionabilidad del banco de canales y, sobre las dinámicas onduladas (Schwendel et al., 2015; Bogoni et al., 2017). Los contrastes topográficos y sedimentarios se producen mediante el transporte selectivo y la deposición de sedimentos (Nanson y Croke, 1992; Van de Lageweg et al., 2014). Todos estos procesos se relacionan con las variaciones de los caudales líquidos, como consecuencia de las precipitaciones, el cambio de uso de las tierras, la granulometría, el volumen de los sedimentos aportados por las corrientes desde la cuenca alta y el carácter fácilmente erodable de las barrancas y de los lechos. Los canales y meandros abandonados favorecen la formación de estructuras sedimentarias preservadas en toda la llanura de inundación. Debido al gran espacio de alojamiento, contribuyen al equilibrio global de sedimentos del sistema de planicie de inundación (Gay et al., 1998; Constantine et al., 2010; Grenfell et al., 2012), además son el resultado de procesos morfodinámicos, como los cortes de canal, por los que un río disminuye su sinuosidad y complejidad, asegurando así el establecimiento de formas evolutivas estacionarias (Camporeale et al., 2005; Frascati y Lanzoni, 2010). 
En los canales naturales, generalmente se reconocen dos tipos de cortes: los hechos por desborde y los hechos por tangencia. Los cortes de un meandro por desborde (chute cutoff) son desviaciones de corrientes, relativamente largas, que se producen cuando un bucle sinuoso es cortado por un nuevo canal que se forma a través de la planicie de inundación encerrada por el bucle (Constantine et al., 2010). Con mayor frecuencia, se forman en canales anchos con grandes curvas, altas descargas, bancos poco cohesivos, escasa vegetación y gradientes altos (Howard y Knutson, 1984) y se forman en cauces meandriformes cuando las aguas de inundación ya no pueden ser contenidas dentro del canal principal. El nuevo canal, más corto y de mayor pendiente, transporta la descarga del río.

Estos cortes pueden desarrollarse durante un largo período (Gay et al., 1998), con solo un flujo de agua de inundación al principio, o durante un solo evento de inundación (Iwasaki et al., 2016). Por lo tanto, su ocurrencia está relacionada con las inundaciones, ya que se requieren altos niveles de agua y altas tasas de transporte de sedimentos de fondo (Howard, 1996; Zinger et al., 2011; Van Dijk et al., 2014). Este proceso produce el acortamiento de la trayectoria del río y el incremento de la pendiente y de la capacidad de transporte de sedimentos, por lo que el cauce tiende a profundizarse, ajustar su ancho y acelerar la migración del río (Morais et al., 2016; Schwenk y Foufoula-Georgiou, 2016).

Sin embargo, Viero y sus colaboradores (2018) relacionan hidrogramas de descarga de la cuenca del río Sacramento, California (U.S.A), y modelos de elevación digital del terreno con imágenes Landsat que muestran etapas significativas en la incisión de los canales producidos por desborde (chute cutoff), comprobando así que las vías preferenciales de escurrimiento en la planicie de inundación tienen una gran influencia en la formación de conductos. Esto implica que, para modelar con precisión el inicio del corte del canal, se deben tener en cuenta la configuración real de la planicie de inundación y el flujo dentro del canal principal y las áreas adyacentes. En cambio, los cortes por tangencia se producen cuando la sinuosidad local se vuelve tan grande que las curvas adyacentes se intersectan entre sí por tangencia (neck cutoff), lo que lleva a la formación de un bucle abandonado (oxbow lake), cuando la sedimentación cierra los extremos de éste (Hooke, 1995; Howard, 1996).

El sector central de la provincia de Tucumán, Argentina, presenta una densa red de drenaje cuyo colector principal es el río Salí. Los tributarios más importantes son los ríos Lules, Famaillá, Los Sosa, Chico, Medina, Seco, Balderrama y Gastona, los cuales tienen sus nacientes en la ladera oriental del cordón del Aconquija (Figura 1). Estos cauces han presentado modificaciones en sus diseños fluviales en la cuenca media-baja, mismas que han sido mencionadas por numerosos autores y consideradas como indicadores de degradación de las cuencas de aporte. Sayago y Cuenya (1990), reconstruyeron el patrón paleofluvial de los ríos Gastona y Medina y concluyeron que la continua degradación de las tierras en las cuencas de aporte produjo la disminución de la sinuosidad, pasando de así de un diseño meandroso a uno entrelazado, como consecuencia del aumento de la carga sólida. Sayago (1992) realizó un trabajo sobre el deterioro del ambiente en el Noroeste Argentino basándose en los conceptos de "umbral extrínseco" de Schumm (1977). Este autor analizó los efectos de las modificaciones del diseño de drenaje de un sistema fluvial cuando es influido por la disminución de la cobertura vegetal en las laderas de la cuenca, la erosión de los suelos, y el incremento de las precipitaciones. Guido y Busnelli (1993) encontraron una estrecha relación entre los parámetros geométricos de las cuencas analizadas y los hidrogramas de crecientes. Sayago y Toledo (1996) y Toledo et al. (2001) determinaron que el aporte de sedimentos al embalse Río Hondo en el lapso 1973-1990 fue considerablemente constante, lo cual modificó el diseño fluvial de los cursos que desembocaban por separado en el mismo, hasta unirse en una intrincada red de canales de diseño meandriforme a entrelazado, a causa de la degradación de las cuencas de aporte y el incremento de las precipitaciones. Trabajos sobre riesgo de inundación de Arcuri (1995) en la 
cuenca del río Medinas y de Busnelli (2009) en el río Gastona se refieren también al diseño de cauces fluviales. Busnelli y Horta (2014) realizaron un estudio morfométrico y de metamorfosis fluvial en las cuencas de los ríos Gastona, Medinas-Chico, Seco y Balderrama, observando que la torrencialidad disminuye desde la cuenca del Gastona, Medinas-Chico, Seco y Balderrama, mientras que la metamorfosis de mayor a menor es: Seco, Gastona, Medinas-Chico y Balderrama. Díaz Gómez et al. (2017) estudiaron las características morfométricas de las cuencas hidrográficas del faldeo oriental de la Sierra del Aconquija y las sierras del sudoeste de la provincia, concluyendo que la cobertura y el uso del suelo en las cuencas estudiadas son factores que podrían incrementar o amortiguar la respuesta hidrológica ante eventos extremos de precipitación.

Con el propósito de contribuir a un mayor conocimiento sobre el diseño y evolución del sistema fluvial en la región, en este estudio se analizarán previamente las características generales de la cuenca del río Seco, ubicada sobre la ladera oriental de la sierra del Aconquija, piedemonte y llanura aluvial. Posteriormente, se realizará el estudio del área de aporte efectiva al sistema de meandros, que, en el caso del río Seco, se circunscribe a una subcuenca ubicada en la cuenca media-alta del rio homónimo.

En el tramo en estudio del río Seco (Figura 1) se apreciaron importantes variaciones en la sinuosidad del cauce activo, como consecuencia de procesos de cortes de meandros chute cutoff y neck cutoff. En relación con lo observado, se plantearon los siguientes objetivos: realizar un análisis cualitativo y cuantitativo de las variaciones en la geometría de los meandros, establecer la relación con las variables de control a través del estudio de la subcuenca de aporte y del sistema climático de la región y estimar la pérdida de tierras agrícolas por procesos de erosión de márgenes.

El presente estudio intenta fortalecer y clarificar las interpretaciones de la dinámica hidrológica, entendiendo que los ríos son sistemas naturales complejos y que, a la vez, constituyen un elemento clave en la dinámica ambiental y en la planificación territorial (Ollero, 2007). La morfología del cauce es un indicador de la naturalidad de la cuenca vertiente. El desconocimiento de la dinámica natural de los sistemas fluviales, de los cauces y de las riberas ha acarreado graves consecuencias ambientales (Ollero et al., 2007).

\section{Materiales y métodos}

Para reconstruir la evolución del cauce del río Seco, se han empleado 20 imágenes satelitales Landsat y 2 imágenes Sentinel 2B, comprendidas en el lapso temporal 1972- 2017 y descargadas de Earth Observing System (EOS)-Land Viewer (2018). Con base en ellas se realizó la digitalización del cauce principal. Asimismo, se utilizó el software libre Qgis 2.18.27 with Grass 7.4.2 (2016) y el aplicativo Google Earth (2018), que posee imágenes satelitales de alta resolución espacial. Las herramientas más utilizadas de este aplicativo fueron: el historial de imágenes, la herramienta de navegación y zoom.

Con el complemento Semi-Automatic Classification Plugin (SCP) de Qgis 2.18.27 with Grass 7.4.2 (2016) se realizaron clasificaciones supervisadas de la cobertura vegetal en la subcuenca de aporte al sistema de meandros, utilizando, con el propósito de cuantificar los cambios en la cobertura boscosa y en los cultivos, imágenes satelitales Landsat de los años 1975 y 2005 además Sentinel del año 2017.

Gracias al complemento Análisis del Terreno de Qgis 2.18.27 with Grass 7.4.2 (2016) se procesó un Modelo Digital de Elevación (MED) SRTM1S28W066V3 (2014), con resolución de 1 segundo de arco, equivalente a $30 \mathrm{~m}$. Las herramientas de Grass están ordenadas en una lista de Módulos, con los cuales se realizan los procesos que dan como resultado los mapas vectoriales. Se realizó también el pre-procesamiento del MED, paso necesario para asignarle valores altimétricos a todos los sumideros que no lo poseen. Con el MED sin sumideros se obtuvo el mapa raster de 


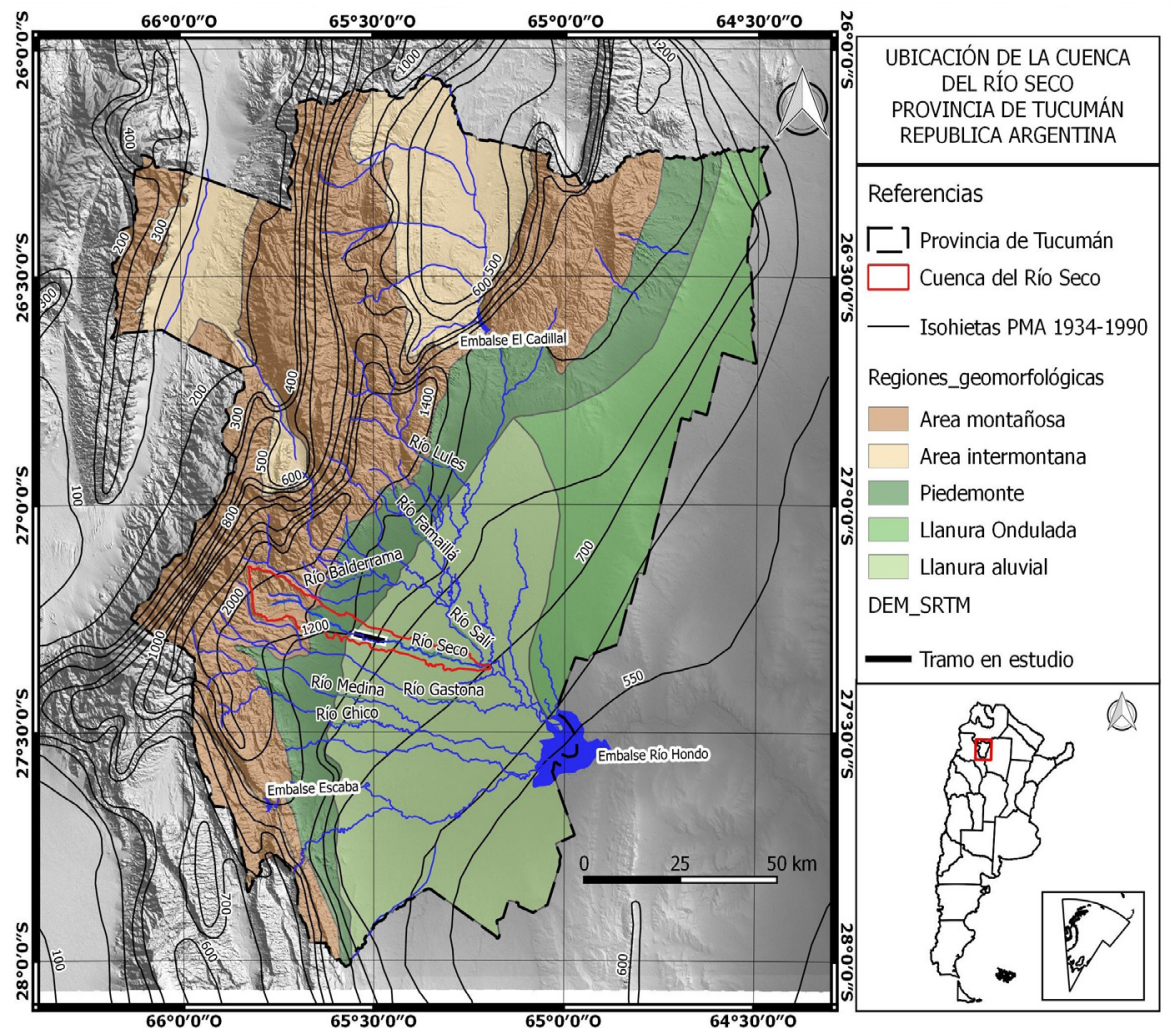

la subcuenca hidrográfica y de la red de drenaje, los que fueron vectorizados y exportados a Qgis en formato shape, mientras que con el MED sin depresiones se obtuvieron además los mapas de pendientes y de curvas de nivel de la subcuenca.

El mapa de suelos fue obtenido de la página web del Instituto Nacional de Tecnología Agropecuaria (2018), el mapa geomorfológico fue obtenido por digitalización de un mapa escaneado y georreferenciado de la versión papel de Sayago et al. (1998a) y el mapa de isohietas de precipitación media anual para el periodo 1934-1990 fue obtenido de Bianchi et al. (2005).

A partir del procesamiento de los datos pluviométricos obtenidos de la Estación Experimental Agroindustrial Obispo Colombres, Sección Agrometeorología (2018), y de la Secretaría de Infraestructura y Política Hídrica de la Nación (2018), se confeccionó un mapa de isohietas de precipitación media anual para la cuenca del río Seco, en el lapso temporal 2008-2017. De la última página mencionada, se descargaron, además, registros de caudales líquidos y sólidos obtenidos en la Estación de Aforos Ruta Nacional 157, con los cuales se confeccionaron hidrogramas de descarga de la cuenca para el lapso temporal 2004-2017. Se realizaron dos campañas para describir las características de los sedimentos de las barrancas afectadas por los procesos erosivos, relevar y definir rasgos erosivos en el piedemonte y la llanura, medir las pendientes del terreno y del cauce con clinómetro marca Suunto y corroborar la información obtenida por teledetección en gabinete.

Los parámetros adoptados para definir la geometría de los meandros tomados de Leopold y Wolman $(1957,1960)$ y Leopold et al. (1964) en el tramo considerado son los siguientes: 1-Longitud del talweg: longitud del meandro medida a lo largo del talweg; 2- Ancho del canal: se obtiene midiendo la distancia entre ambas orillas; 3- Radio de curvatura: distancia entre el centro de curvatura y el talweg, a lo largo del meandro; 4-Longitud de onda: distancia que une en línea recta dos ápices alternos medida desde el centro del canal; 5-Amplitud: distancia transversal a la dirección 
media del río tomada desde el ápice del lóbulo del meandro hasta el centro de su longitud de onda; da una idea del espacio ocupado por las curvas del río en su desplazamiento lateral y 6 - Sinuosidad: relaciona la longitud del talweg y la distancia en línea recta entre dos puntos sobre el mismo y permite inferir la divagación de los meandros con respecto a la dirección media del eje del río. La clasificación de los diseños de cauce se basó en Miall (1977).

Para abordar el estudio morfométrico de la subcuenca de aporte se aplicaron los criterios de Horton (1945) y Strahler (1974). Posteriormente, se analizaron los parámetros asociados a la subcuenca que intervienen directamente en el hidrograma de descarga, tales como: 1-Área (A); 2-Perímetro (P); 3-Longitud (L); 4-Ancho $(\mathrm{H})$; 5 Altura máxima (Hmax) y Mínima (Hmin); 6-Factor forma (Ff): relación entre el área de la cuenca y el cauce principal; 7-Índice de alargamiento (Io): cociente entre la longitud y el ancho máximo de la cuenca; 8-Coeficiente de compacidad (Kc): relación entre el perímetro y el área de la cuenca; 9-Índice de Circularidad (Ic): relación entre el área y el perímetro de la cuenca. Se analizaron además los parámetros relativos al drenaje; 10-Número de cauces; 11- Longitud de los cauces; 12-Orden de corrientes; 13-Densidad de drenaje (Dd): relación existente entre la longitud total de los cursos de agua y el área de la cuenca; 14-Frecuencia de cauces $(\mathrm{Fc})$ : cociente entre el número total de cauces y el área de la cuenca; 15-Relación de longitud $(\mathrm{Rl})$ : relación existente entre la longitud media de los cauces de un orden dado y la longitud media del orden inmediato inferior; 16-Relación de bifurcación $(\mathrm{Rb})$ : cociente entre el número total de ríos de un orden dado y el número total de ríos del orden inmediato superior; 17-Coeficiente de almacenamiento (RHO): cociente entre $\mathrm{Rl}$ y $\mathrm{Rb}$; 18-Extensión media del escurrimiento superficial (E); 19-Coeficiente de torrencialidad (Ct): cociente entre el número de cauces de orden 1 y el área de la cuenca y Tiempo de concentración (Tc): relación entre la longitud del cauce principal y la diferencia de altura entre los extremos del mismo.
Para el cálculo de los caudales entregados por la subcuenca de aporte se aplicó el Método de la Curva Número (Natural Resources Conservation Service, 1986 y 2004).

El Método de la Curva Número utiliza como dato de entrada la intensidad de lluvia en la cuenca, asumiendo que en la misma cuenca diferentes lluvias provocarán diferentes escorrentías y que una misma lluvia provocará diferentes escorrentías con distintos usos del suelo, en especial cuando se analiza un amplio lapso temporal. Se consideró el evento de lluvia que generó mayor escorrentía en el período 2008-2017, obtenido de la Estación Experimental Agroindustrial Obispo Colombres, Sección Agrometeorología, (2018). Luego se procedió a determinar $\mathrm{S}$ (diferencia máxima potencial entre la lluvia caída y la escorrentía generada) mediante la siguiente ecuación:

$\mathrm{S}=(25400 / \mathrm{CN})-254$

$\mathrm{CN}=$ Número de curva.

El número de curva $(\mathrm{CN})$ toma un valor de $0 \mathrm{a}$ 100 según sea su capacidad de generar escorrentía superficial. Valores cercanos a 0 representan condiciones de permeabilidad muy alta, mientras que valores cercanos a 100 representan condiciones de impermeabilidad. El número de curva se obtiene de tablas (Natural Resources Conservation Service, 1986 y 2004). Este valor depende del tipo hidrológico de suelo, el uso y tratamiento de la tierra y la condición precedente de humedad (lluvia total caída durante los cinco días anteriores al evento).

La escorrentía Q (mm) se calcula utilizando la siguiente ecuación:

$$
\mathrm{Q}(\mathrm{mm})=(\mathrm{I}-0.2 \mathrm{~S}) 2 / \mathrm{I}+0.8 \mathrm{~S}
$$

$\mathrm{S}=$ diferencia máxima potencial entre la

lluvia caída y la escorrentía generada.

$\mathrm{I}=$ Intensidad de precipitación $(\mathrm{mm} / \mathrm{h})$.

Dichas ecuaciones fueron adaptadas a una planilla de cálculo utilizando Microsoft Excel (2013), con lo que se determinó la escorrentía Q para un 
evento de lluvia, considerando la cobertura de la subcuenca (cultivos, monte y urbano) y superficies que ocupaban en los años 1876, 1975, 2005 y 2017, longitud y diferencia entre la altura máxima y mínima del cauce y las condiciones de humedad precedente.

La información gráfica y metadatos obtenidos fueron trabajados en un entorno SIG, con el propósito de establecer las relaciones espaciales entre los diferentes elementos analizados e inferir cuáles fueron los componentes del medio físico que favorecieron la movilidad lateral y vertical del sistema fluvial en el tramo considerado.

\section{Características generales de la cuenca del río Seco}

La cuenca del río Seco se sitúa en el sector centro, oeste de la provincia de Tucumán (Figura 1), la cual se ubica en la transición entre dos espacios morfoestructurales de la Argentina: la llanura chaqueña al este y los cordones montañosos preandinos al oeste (Sayago et al., 1998a). Abarca parte de la provincia geológica de Sierras Pampeanas Noroccidentales (Caminos, 1979) y la llanura Chaco Pampeana.

En el relieve de la cuenca pueden diferenciarse tres regiones geomorfológicas: 1) área montañosa, 2) el piedemonte y 3) la llanura aluvial.

La primera se caracteriza por presentar laderas húmedas cubiertas y ocupa parte de la ladera oriental de la Sierra del Aconquija, compuesta por rocas del basamento ígneo-metamórfico del Precámbrico-Cámbrico (Rassmus, 1918; González Bonorino, 1951). En la segunda se encuentran abanicos aluviales y valles fluviales, donde se observan cenoglomerados, fanglomerados, limos y gravas fluviales que cubren los sedimentos del Terciario compuestos predominantemente de areniscas con intercalaciones de arcillitas y tobas. En la tercera se aprecian planos interfluviales eólicos, paleocauces, cauces actuales, planos de divagación paleofluvial y planos deprimidos anegables.En esta última también se encuentran sedimentos loéssicos y paleosuelos, que alternan con los de origen fluvio-aluvial asignados al Cuaternario (Sayago et al., 1998a). Las capas loéssicas alcanzan mayor desarrollo hacia el este (González Bonorino, 1951).

Las pendientes en el piedemonte varían entre el 5 al 10\% y en las laderas, entre el 10 al 70\%. En la llanura aluvial y deprimida las pendientes son de bajo gradiente de 0 a $2 \%$.

Este fuerte contraste de relieve entre las tres regiones, tal como se observa en el mapa de pendientes de la Figura 2, incrementa los riesgos de erosión hídrica y movimientos en masa en la zona montaña y pedemontana, y de los flujos torrenciales, inundaciones y sedimentación en las zonas planas, reuniendo así las condiciones de una típica toposecuencia erosiva (Sayago, 1992). El escurrimiento superficial es rápido en las laderas y piedemonte y lento a impedido con encharcamientos en la llanura aluvial y deprimida. Los suelos de la zona montañosa se desarrollan bajo un clima húmedo, con elevado aporte de materia orgánica, pero con fuertes pendientes y sustrato rocoso casi en superficie. Los sectores donde el material sedimentario que cubre el sustrato rocoso es de mayor espesor y/o las pendientes menos pronunciadas muestran perfiles más desarrollados. Los suelos dominantes pertenecen al orden Inceptisol, suelos poco evolucionados, algo más que los Entisoles, y se caracterizan por presentar, por lo general, un epipedón úmbrico oscuro, rico en materia orgánica (Puchulu y Fernández, 2014).

En el piedemonte, donde se desarrolla la mayor producción agrícola de la provincia, se encuentran dos tipos de suelos: Por un lado, los más evolucionados (más de $3 \mathrm{~m}$ de espesor), con una clara horizontalización y enriquecidos con carbono orgánico, $\mathrm{pH}$ neutro a ligeramente ácido y texturas predominantemente finas (franco arcillosa), los cuales están representados principalmente por Molisoles (subgrupo Argiudoles típicos y Hapludoles Taptoárgicos) sobre pendientes más suaves y material originario limo-arcilloso, y, por el otro, los menos desarrollados son Molisoles (Hapludoles énticos), asociados a lomadas bajas del piedemonte, conos aluviales y vías de escurrimiento menores (Puchulu y Fernández, 2014). 


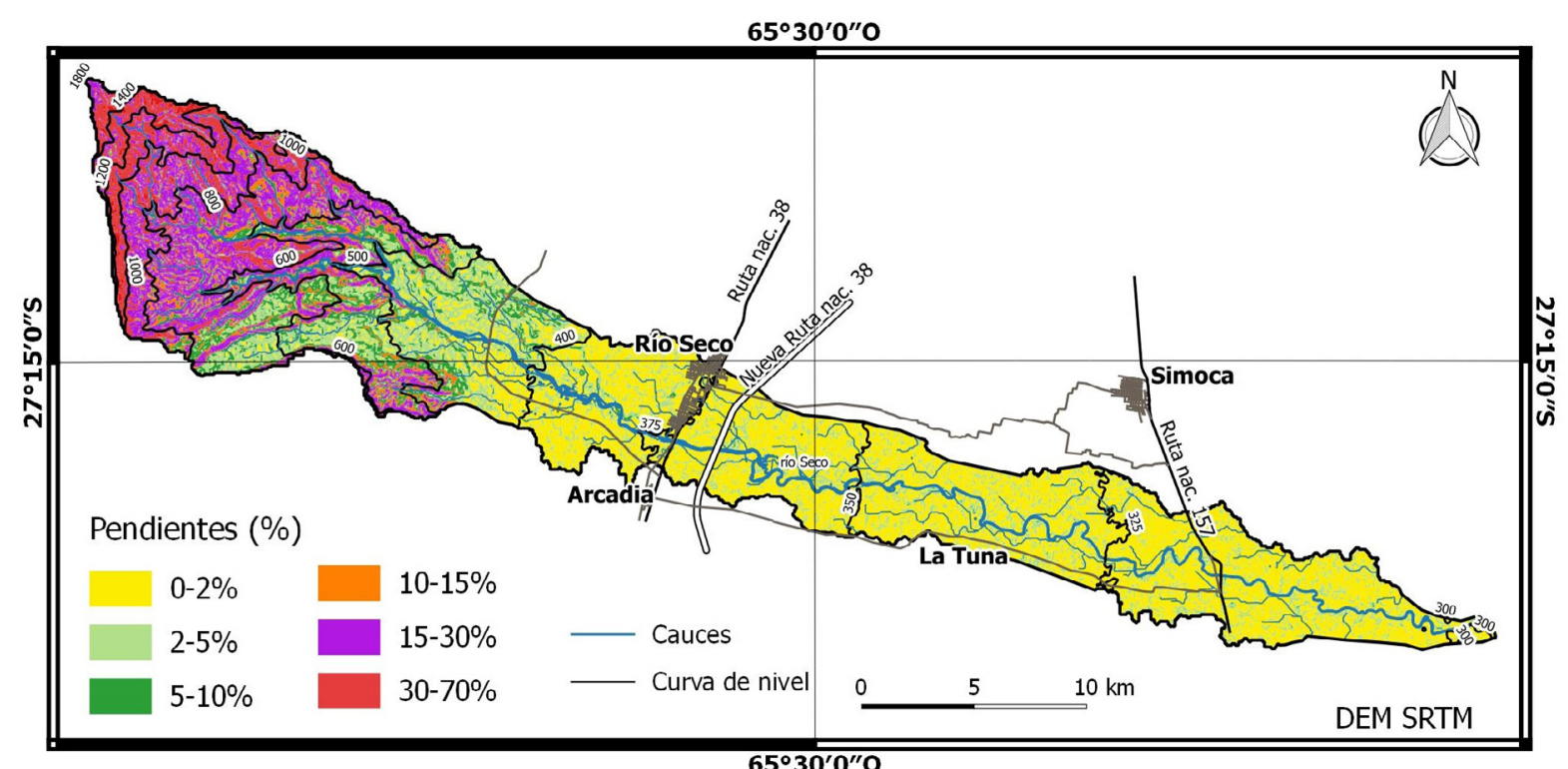

Figura 2 Mapa de pendientes de la cuenca del río Seco, provincia de Tucumán.

En la llanura aluvial se encuentran suelos de preponderante granulometría arenosa y limosa (Sayago, 1992). En la Figura 3 se muestra el mapa de suelos del Instituto Nacional de Tecnología Agropecuaria (2018), en donde puede observarse que en superficie se encuentran Inceptisoles (suelos jóvenes que carecen de horizontes diagnósticos), Entisoles (suelos jóvenes sin desarrollo del perfil ni horizonte diagnóstico, que se desarrollan sobre materiales aluviales estratificados y, ocasionalmente, se encuentran saturados por agua) y Molisoles (suelos minerales que tienen un horizonte superficial muy oscuro, coloreado y rico en bases, casi todos estos suelos tienen un epipedón mólico y muchos también poseen un horizonte de diagnóstico subsuperficial argílico, nátrico o cálcico).

Las observaciones realizadas en los perfiles de pozos de los archivos del Departamento de Perforaciones de la Dirección Provincial del Agua por Molina (1988) para la llanura aluvial y en los perfiles expuestos en las márgenes del cauce (Figuras 4 y 5) muestran capas de secuencias fluviales compuestas predominantemente de arenas, limos, arcillas y gravas con clastos de 3 a $25 \mathrm{~cm}$ de diámetro. Estos sedimentos son observados en las curvas de los meandros, donde son afectados por erosión lateral de cauce.
Las texturas arenosas y limosas presentan una extrema susceptibilidad erosiva (Bergsma, 1982), por lo que las crecidas remodelan el paisaje fluvial a distintas escalas, ocasionando importantes pérdidas de suelos productivos por erosión lateral, la cual incluye el desplome de los horizontes edáficos superiores. El proceso de erosión de márgenes es muy activo durante las crecidas y provoca grandes modificaciones en la geometría de meandros.

Sobre la ladera oriental de La Sierra del Aconquija se desarrolla el bosque montano subtropical o bosque de Las Yungas, por arriba de los 500 msnm y en pendientes que superan el 10\%, caracterizado, además, por abundantes especies arbustivas y epífitas florales y del monte chaqueño en la llanura aluvial y deprimida. Estas masas vegetales fueron perdiendo representatividad como consecuencia del avance de los cultivos, la urbanización y la extracción con fines comerciales. La explotación forestal de los bosques húmedos del Noroeste Argentino se inició en la época de la colonia, principalmente en Tucumán (Levene, 1939) para la construcción de carretas y muebles rústicos de la época. Posteriormente, con el ingreso del ferrocarril en 1876 (Diario La Gaceta de Tucumán, 28 de diciembre de 2012) se estimuló el desarrollo de la producción azucarera, 
cuyos orígenes datan del siglo XVII (Malizia et al., 2014). Aunque la producción de caña ya existía en Tucumán de forma artesanal, solo adquirió dimensiones masivas a fines del siglo XIX, después de que el gobierno federal aumentara los impuestos a la importación de azúcar del Brasil. Debido a que el piedemonte tucumano fue deforestado para destinarlo a las plantaciones, se formó una angosta franja donde se concentró la mayor parte de la población y se ubicaron las ciudades más importantes, unidas primero por el ferrocarril y luego por la Ruta 38 (Fondo Internacional de Desarrollo Agrícola, 2011).

La superficie cosechable total con caña de azúcar para Tucumán en la zafra 2017 fue estimada en 269530 ha, de las cuales 22810 corresponden al departamento Monteros (Estación Experimental Agroindustrial Obispo Colombres, 2017), donde se ubica la cuenca del río Seco.

Actualmente, la caña de azúcar es el principal cultivo de la cuenca y ocupa la mayor parte del área de estudio. Estos cultivos se desarrollan en la zona pedemontana, llanura aluvial y deprimida. Le siguen en importancia los cultivos de citrus y arándanos.

En el piedemonte, la caña de azúcar se cultiva en áreas de entre $1 \%$ a $5 \%$ de pendiente. Las plantaciones en relieves con pendientes erosivas se realizan en surcos siguiendo las curvas de nivel, complementándolas con el manejo de la cobertura con maloja después de la cosecha, dado que el régimen de precipitaciones está en el orden de los $1200 \mathrm{~mm}$ anuales, fuertemente concentrado en el período estival, lo que incentiva los procesos de erosión hídrica. Esta práctica permite controlar la velocidad del escurrimiento superficial, incrementar el tiempo de concentración en los cauces, y favorecer la infiltración en el suelo.

En la llanura aluvial y deprimida se producen encharcamientos que afectan las labores de cosecha. El período de zafra se lleva a cabo de mayo a octubre, durante la época seca, por lo que deben realizarse acciones tempranas de preparación de suelos y plantación para evitar que el suelo esté desnudo al inicio del período de lluvias, disminuyendo así el riesgo de erosión por impacto de las gotas de lluvia.

En el piedemonte superior, zona que presenta un buen drenaje dado por la pendiente del terreno y la permeabilidad de los suelos, se cultivan citrus, los cuales ocupan menos superficie que los cultivos de caña de azúcar y se hacen en curvas de nivel en terrenos de pendientes pronunciadas de hasta el $7 \%$, con cobertura cespitosa para no dejar el suelo

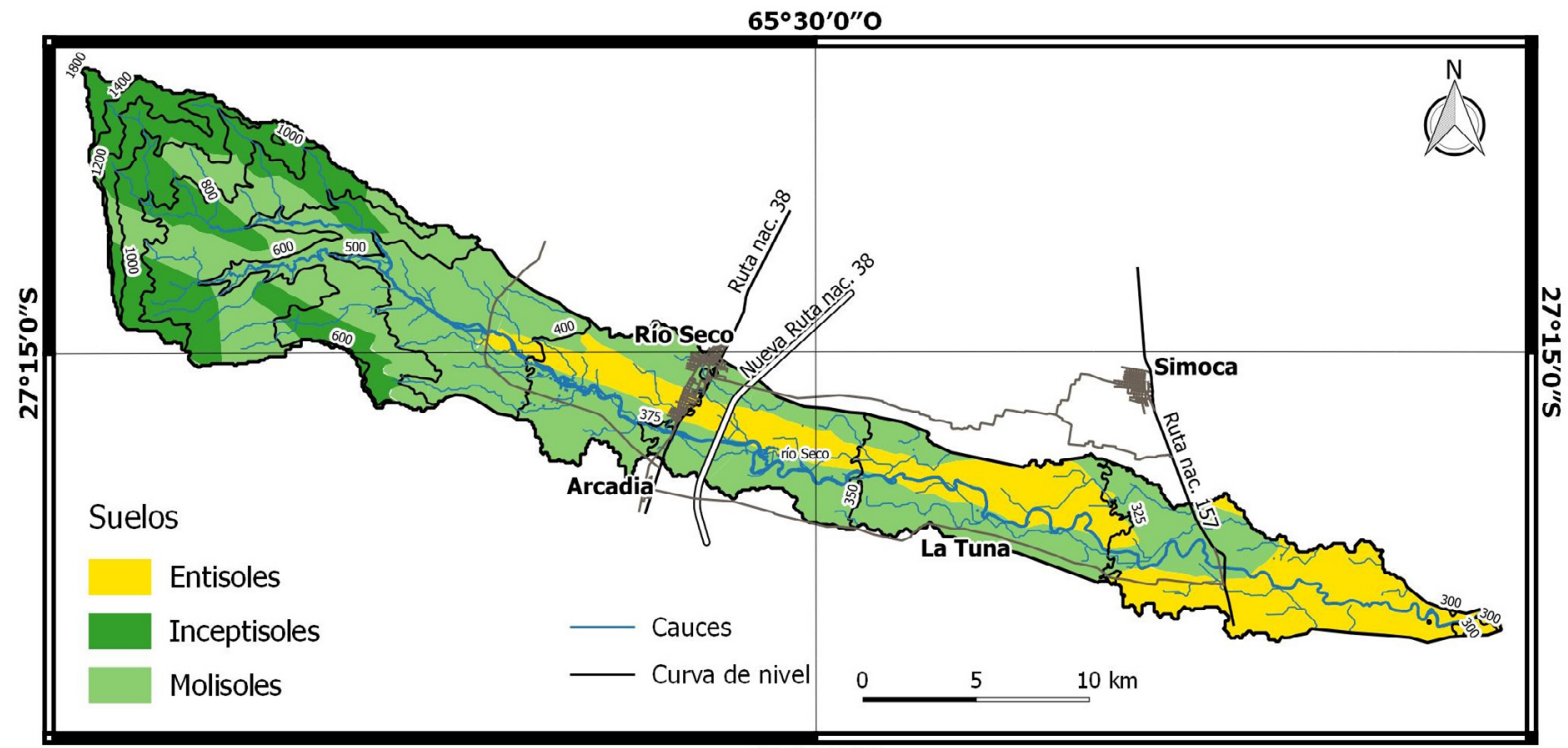

$65^{\circ} 30^{\prime} 0^{\prime \prime} 0$

Mapa de suelos de la cuenca del río Seco, provincia de Tucumán. 
descubierto. Si bien los campos dedicados a estos cultivos no muestran procesos erosivos severos, en la temporada de lluvias aportan mayor escurrimiento superficial a los cauces. En el piedemonte se observan también cultivos de arándanos que mantienen una cobertura plástica en los primeros años de desarrollo para conservar la humedad del suelo.

Como consecuencia del continuo avance de la deforestación y las prácticas de laboreo, se favoreció la degradación del paisaje, debido a la ocupación de tierras moderadamente aptas para el cultivo (Sayago, 1992). Así pues, los suelos dedicados durante años a la agricultura, y que han soportado una fuerte presión antrópica, presentan hoy una notable disminución de su capacidad productiva original. Por su parte, el aumento superficial de las áreas pobladas hacia el piedemonte extiende la superficie impermeable e incrementa el riesgo de inundación y anegamiento, ocasionando graves inconvenientes que están ligados a las variaciones climáticas estacionales.

Las lluvias intensas en cortos períodos producen graves alteraciones en la estructura de los suelos (United States Department of Agriculture,
1978) caracterizados por una granulometría limosa (Sayago, 1992). Las texturas limosas presentan una extrema susceptibilidad erosiva (Bergsma, 1982), la que es acrecentada cuando estos suelos se encuentran desprovistos de su cobertura vegetal original y fueron sometidos a fuertes presiones durante los trabajos de labranza. Las partículas del suelo son separadas enérgicamente de la estructura edafológica y transportadas por las corrientes desde los campos de cultivo hasta los cauces principales.

\subsection{GLIMA: ANÁLISIS DE PREGIPITAGIONES}

El clima es subtropical con estación seca. Entre los meses de octubre a marzo se registran abundantes lluvias en un régimen pluvial de tipo monzónico, torrencial y estacional. Durante el verano se registran más del 90\% de las lluvias. En la llanura la temperatura media en invierno es de $10{ }^{\circ} \mathrm{C}$ a 12 ${ }^{\circ} \mathrm{C}$, mientras que en verano la temperatura alcanza un máximo de $42{ }^{\circ} \mathrm{C}$ (Bianchi et al., 2005).

En la Figura 6 se muestran las isohietas de precipitación media anual para el periodo 1934-1990, obtenidas de Bianchi et al. (2005), y

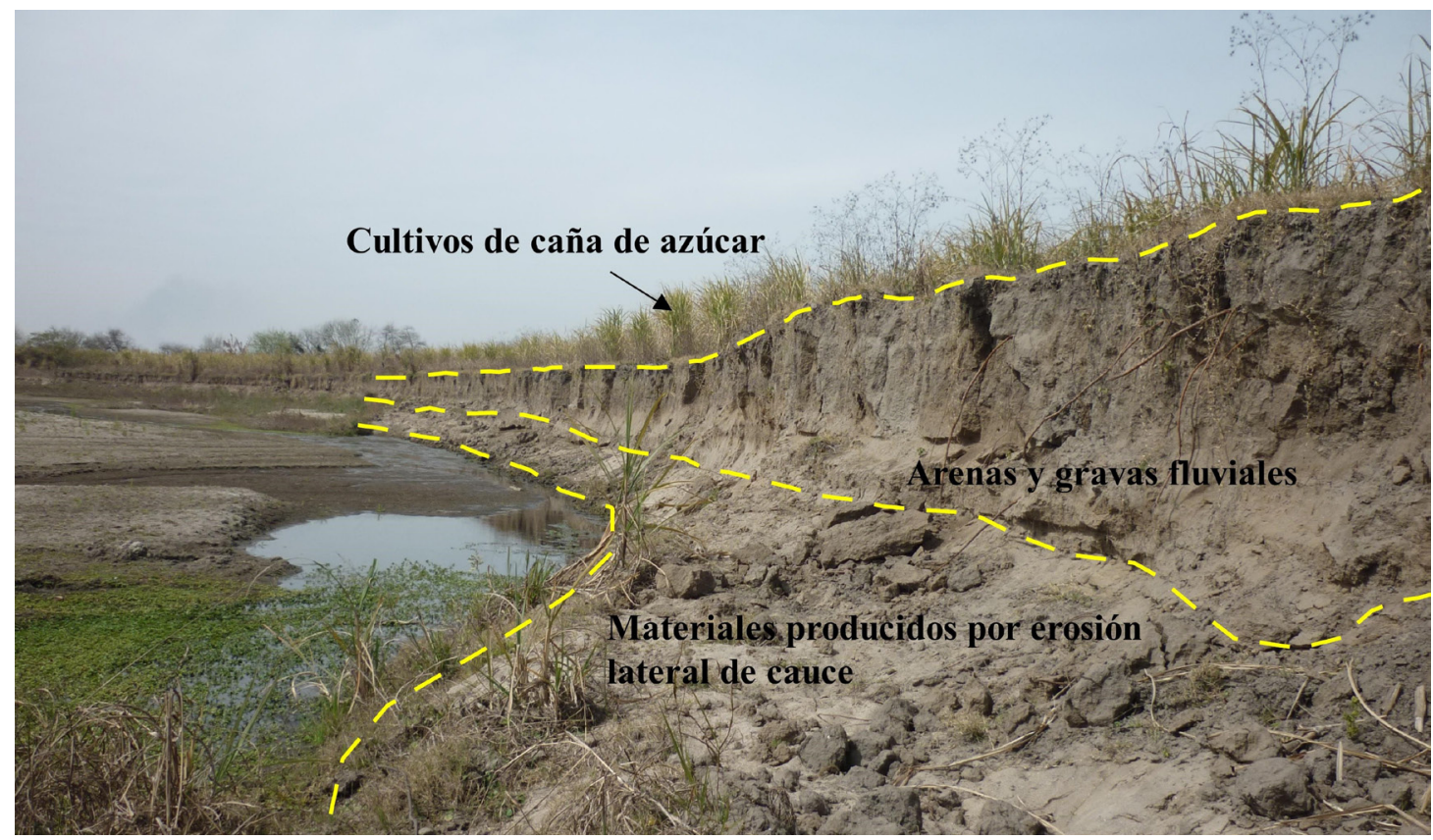

Figura 4 Barrancas de la margen derecha del río Seco, compuestas de arenas y gravas fluviales. Curva de meandro (27 17’56.17"S; $\left.65^{\circ} 31^{\prime 3} 38.65^{\prime \prime} O\right)$. Pueden observarse los cultivos de caña de azúcar. 


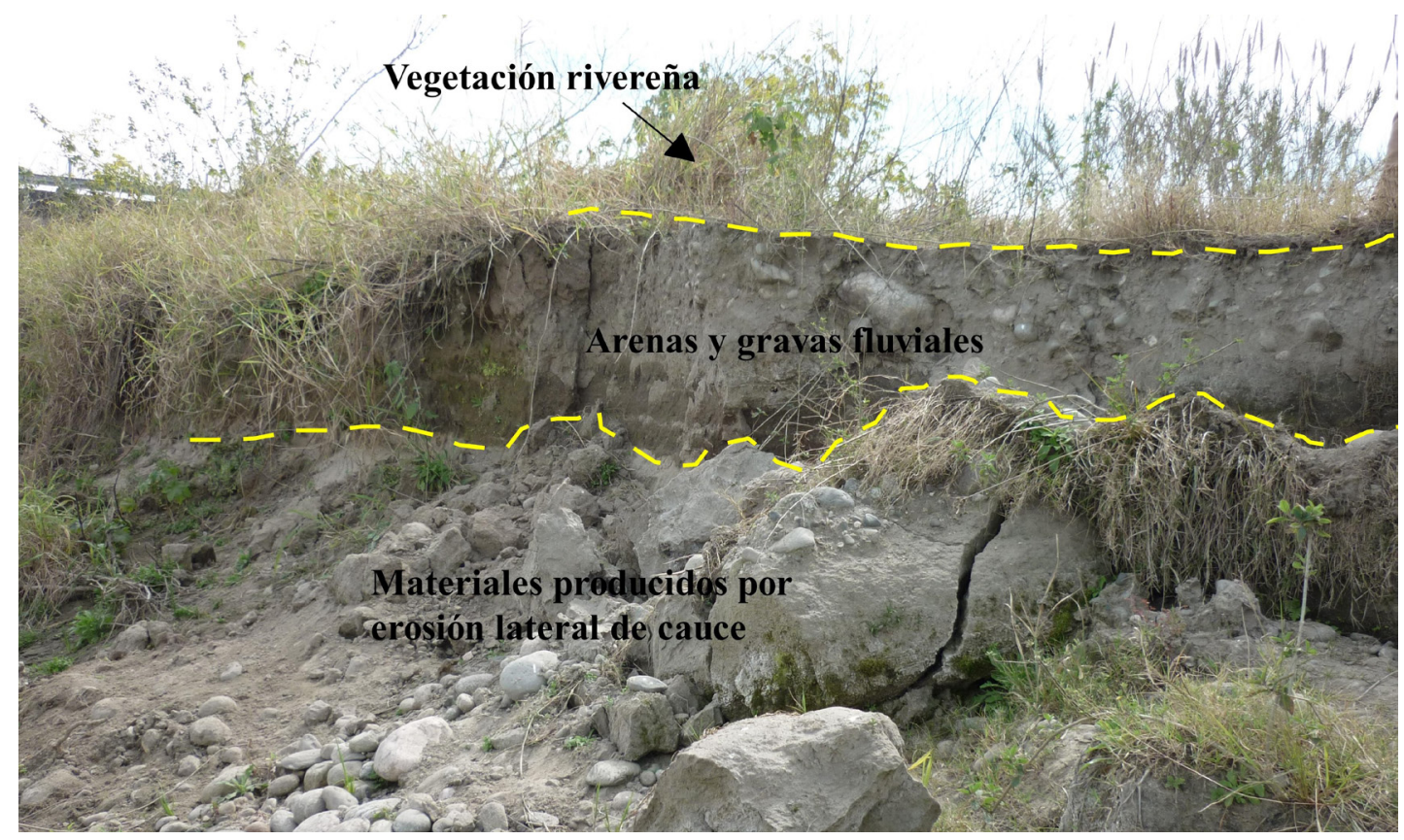

Figura 5 Barrancas de la margen izquierda del río Seco, compuestas de arenas y gravas fluviales (27¹7’5.64”S; 65³2’37.59”O).

las trazadas con los datos de precipitación de la Estación Experimental Agroindustrial Obispo Colombres (2018) y de la Secretaría de Infraestructura y Política Hídrica de la Nación (2018), para la cuenca del río Seco, período 2008-2017. Como puede observarse, para el primer período el rango de precipitaciones varía desde $700 \mathrm{~mm}$ en la confluencia del río Seco con el río Salí, en la llanura aluvial-deprimida, hasta $2000 \mathrm{~mm}$ en la zona montañosa. En contraste, en el lapso temporal 2008-2017 las isohietas de $800 \mathrm{~mm}$ y de 1000 mm se desplazaron hacia el este, mientras que la de $600 \mathrm{~mm}$ se desplazó hacia el oeste. Hacia la zona montañosa, la de $2000 \mathrm{~mm}$ no ha variado considerablemente.

En el Noroeste Argentino, las cadenas preandinas tales como las Sierras Subandinas y las Sierras Pampeanas actúan como barreras contra los vientos húmedos provenientes del anticiclón del Atlántico Sur, originando células de convección orográfica y ejerciendo un importante efecto sobre el clima de la región y en especial sobre las precipitaciones (Bianchi et al., 2005). La Sierra del Aconquija (Figura 1) posee un fuerte gradiente topográfico y su punto más alto es el cerro
El Bolsón de 5550 msnm y el más bajo, el límite entre el piedemonte inferior y la llanura a los 400 msnm, por lo que es muy grande el aumento de las precipitaciones sobre sus laderas, el piedemonte y la llanura (Bianchi et al., 2005). La humedad se condensa por ascenso orográfico en el faldeo oriental de la sierra, entre los 850 y 1300 msnm (Torres Bruchman, 1978; Minetti et al., 1979); hacia la cumbre las precipitaciones decrecen.

En este sentido, toma importancia la ubicación de la cuenca alta del río Seco en cuanto a su capacidad para concentrar mayor cantidad de precipitaciones. Busnelli y Horta (2014) consideraron que su ubicación a media ladera permite captar mayores precipitaciones, lo que explica la elevada sinuosidad del cauce del río Seco.

En la Figura 6 se observa que la cuenca mediaalta, aguas arriba del tramo en estudio, se encuentra entre las isohietas de 1200 a $2000 \mathrm{~mm}$ anuales. Los daños provocados como consecuencia de la severidad de los caudales son testimonios de la intensidad de las precipitaciones. En el mes de febrero de 2016 las crecidas destruyeron el puente sobre el río Seco, ubicado en el piedemonte (Figura 7). Este fenómeno climático afectó también a 


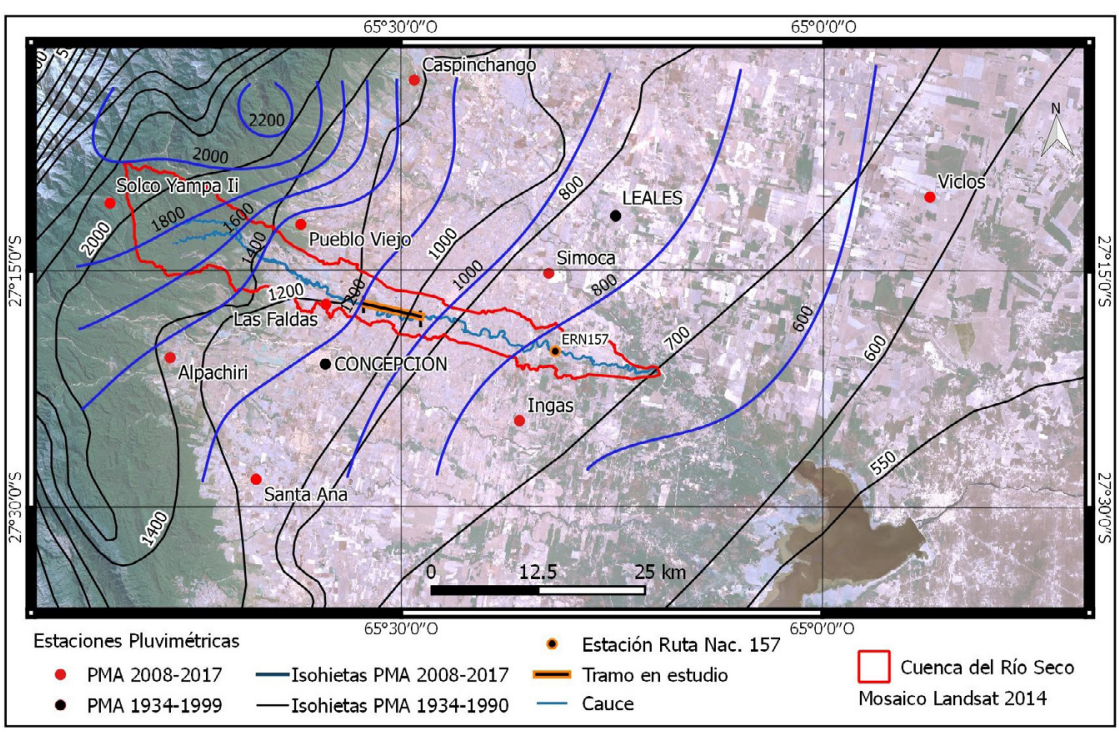

Figura 6 Comparación de las isohietas del período 1943-1990 de Bianchi et al. (2005), con las isohietas del período $2008-2017$ elaboradas a base de los datos de la Estación Experimental Agroindustrial Obispo Colombres (2018) y de la Secretaría de Infraestructura y Política Hídrica de la Nación (2018).

numerosas poblaciones de la provincia, causando el desborde de los ríos y la interrupción del servicio eléctrico y de agua potable. Similares eventos se presentaron en los meses de enero y febrero de los años 2014 y 2015. En las observaciones de campo, luego de uno de los eventos de crecida, se detectó la pérdida de una ha de suelo cultivado con caña de azúcar, superando ampliamente al proceso erosivo que podría producirse en varios años de dinámica hídrica normal. Castañeda y Barros (1994) precisaron que, entre 1956 y 1991, en la mayor parte del territorio argentino al norte de $40^{\circ}$ latitud Sur, el incremento en las precipitaciones medias anuales fue mayor al $10 \%$.

La Figura 8, tomada de Toledo et al. (2001), muestra las curvas de precipitaciones medias anuales de las estaciones pluviométricas El Colmenar, Leales y Concepción. De igual manera, se observa el marcado cambio en el régimen pluviométrico, con incremento del 30\% de las precipitaciones a partir del año1970. Un nuevo análisis de consistencia de los datos utilizados para la construcción de la Figura 8 indicaría un incremento mayor en la media de las precipitaciones, en el orden del 35 al $40 \%$.

\section{Resultados}

\subsection{USO DE LA TIERRA, GAUDALES Y CARACTERÍSTICAS MORFOMÉTRICAS DE LA SUBGUENCA DE APORTE AL SISTEMA DE MEANDROS}

La subcuenca de aporte al sistema de meandros comprende la cuenca alta y parte de la media del río Seco. Abarca una superficie de 21631.34 ha y su máxima altura es de 1818 msnm (a media ladera del Aconquija), mientras que su mínima se encuentra a los 369 msnm. En esta área el uso de la tierra se ha modificado lentamente desde 1975 hasta 2017. La Figura 9 muestra los cambios en la cobertura de la subcuenca y la Tablal resume dichos cambios.

De acuerdo a estos resultados, la superficie con bosque y con cultivos de caña de azúcar ha disminuido durante el período de observación, mientras que las superficies con cultivos de citrus y arándanos se han incrementado. Parte de éstas, donde se cultivaba citrus, fueron transformadas para el cultivo de arándanos. Para el cálculo de la escorrentía se aplicó el Método de la Curva Número (Natural Resources Conservation 


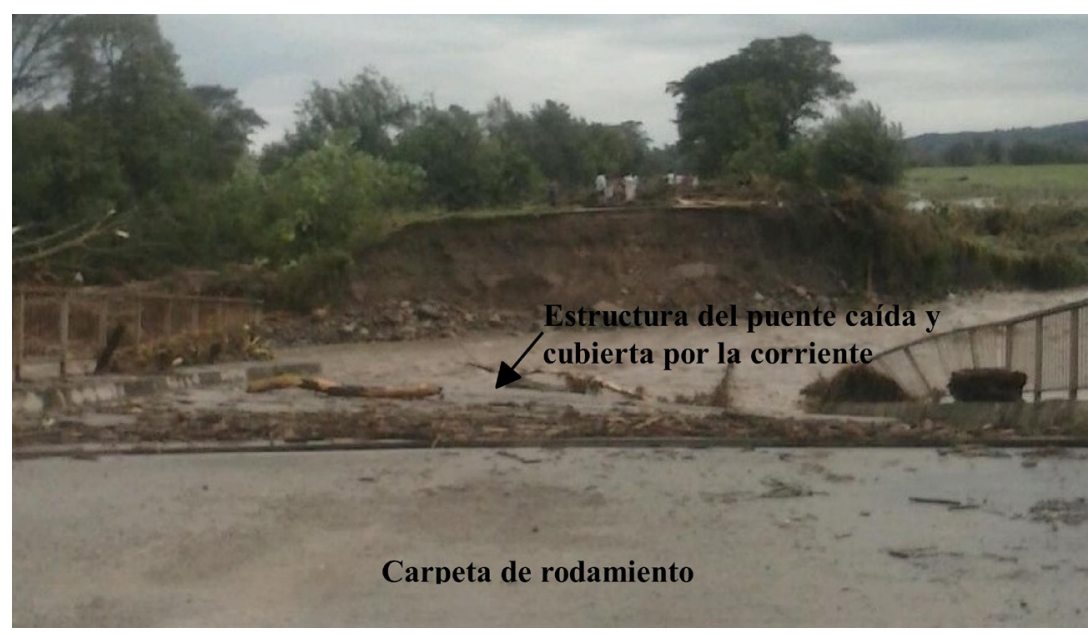

Figura 7 Puente destruido por una creciente del río Seco en el mes de febrero de 2016. (27¹4’29.87”S; 65³8'46.38”O). Disponible en: https://www.eldiario24.com/nota/tucuman/370018/crecida-rio-seco-destruyo-puente-une-sargento-moya-arcadia.html. Consultado en Julio de 2018

Service, 1986 y 2004), utilizando los valores de Curva Número (CN) determinadas para la subcuenca (Tabla 2) para las Condiciones Precedente de Humedad II (CPH II, normal) y III (CPH III, húmedo) y siguiendo el procedimiento detallado en el apartado de Materiales y métodos. En la determinación del $(\mathrm{CN})$ se tuvieron en cuenta las descripciones sobre el uso y tratamiento de la tierra que fueron desarrolladas en el capítulo Características generales de la cuenca del río Seco. Con base en ellas se determinó también el tipo hidrológico de suelo.

La Tabla 3 y la Figura 10 resaltan la influencia de la modificación de la cobertura en el incremento del escurrimiento superficial, en base

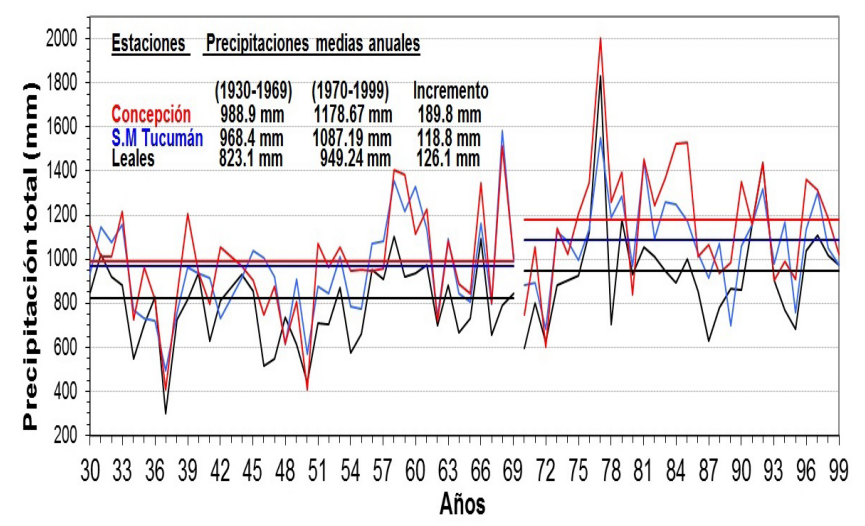

Figura 8 Precipitaciones medias anuales registradas en las estaciones meteorológicas: San Miguel de Tucumán, Leales y Concepción, indicando el incremento registrado en el lapso temporal 1970-1999, en relación al período 1930-1969. a la aplicación del Método de la Curva Número (CN). Los valores utilizados en el cálculo fueron las superficies ocupadas por monte, cultivos y urbano en los años 1975, 2005 y 2017 (Tabla 1) y los valores de CN de la Tabla 2. Se consideró como referencia inicial una cobertura hipotética de monte en toda el área de aporte para el año 1876 (año aproximado en el cual comenzó la explotación de los bosques en Tucumán). Bajo esas condiciones la subcuenca tendría 21631.34 ha con bosque nativo, con lo que habría producido una escorrentía de $3.01 \mathrm{~mm}$ para CPH II y $18.63 \mathrm{~mm}$ para CPH III, utilizando como dato de entrada una intensidad de lluvia de $75 \mathrm{~mm} / \mathrm{h}$, distribuida uniformemente en toda la subcuenca.

Para el año 2017, y con la misma intensidad de lluvia $(75 \mathrm{~mm} / \mathrm{h})$, la escorrentía para $\mathrm{CPH}$ II fue de $7.35 \mathrm{~mm}$ y de 27.47 para CPH III. La diferencia entre estos valores extremos señala que la escorrentía se ha incrementado en $4.34 \mathrm{~mm}$ para CPH II y en $8.84 \mathrm{~mm}$ para CPH III durante el período 1876-2017, como consecuencia de la eliminación de 7092.28 ha de bosques nativos, de las cuales 6317.67 ha se desmontado durante el período 1876 - 1975 y las 774.61 ha durante el período de análisis, entre 1975- 2017 (Tabla 1).

Estos valores dan cuenta de la importancia de la cobertura boscosa en el incremento del tiempo de concentración y en la disminución de la escorrentía. 


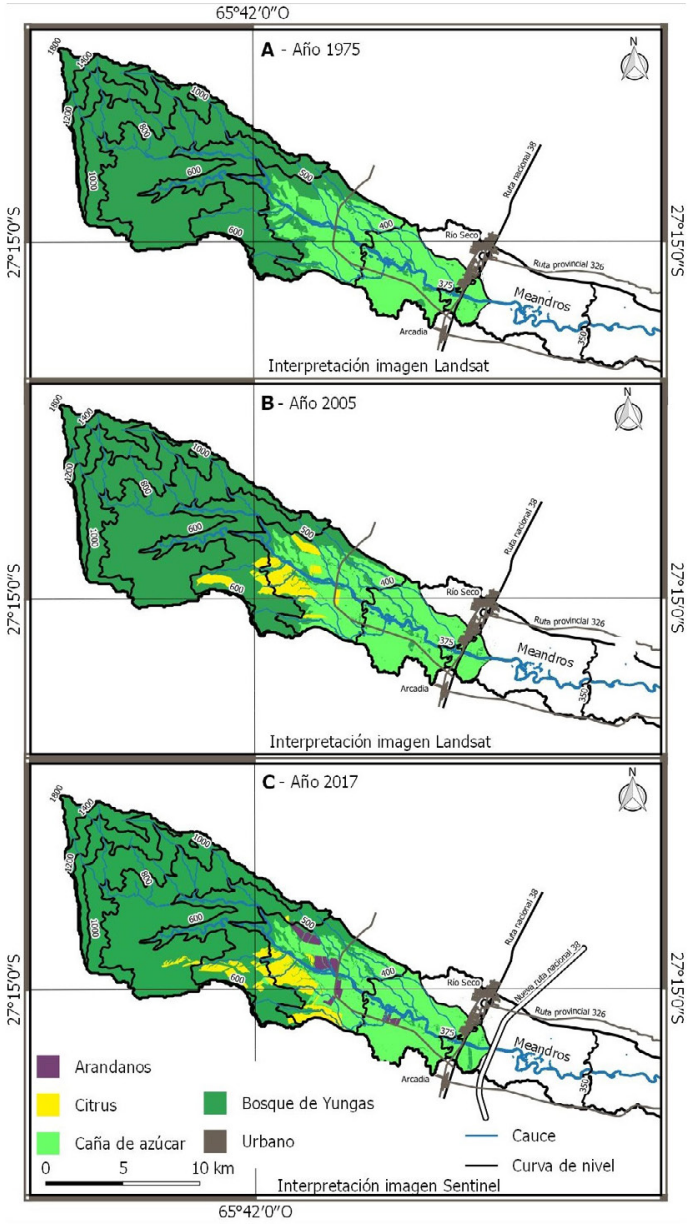

Figura 9 Mapas de uso del suelo de la subcuenca de aporte al sistema de meandros, para los años: 1975, 2005 y 2017.

La atenuación de las curvas CPH II y CPH III en la Figura 10 a partir del año 1975 responde a la disminución de la tasa de desmonte, la cual estaría condicionada por el relieve escabroso de la zona montañosa. La aptitud de uso de estos suelos está limitada parcialmente por su escaso desarrollo y la elevada susceptibilidad a la erosión hídrica y a procesos de remoción en masa (Sayago et al., 1998b). El escurrimiento superficial generado en la subcuenca de aporte se concentra en (PCE), punto de ingreso al tramo en estudio, Figura 11. En este punto, la corriente principal tiene una alta jerarquización (orden 6).

La Tabla 4 muestra los parámetros morfométricos de la subcuenca. El valor de Relación de bifurcación $(\mathrm{Rb})$ promedio es de 4.38. Según Verstappen (1983), los diseños de drenaje con moderada influencia geológica tienen un rango de
Tabla 1. Cambio de uso de los suelos en la subcuenca de aporte al tramo meandriforme A-B, lapso temporal 19752017. Los signos (+) y (-) representan el incremento y la disminución, respectivamente, de la cobertura analizada.

\begin{tabular}{|c|c|c|c|c|}
\hline & \multicolumn{3}{|c|}{ Años } & \\
\hline Cobertura (ha) & 1975 & 2005 & 2017 & Cambios \\
\hline \multirow{2}{*}{ Monte } & 15313.67 & 15087.72 & 14539.06 & \multirow{2}{*}{-774.61} \\
\hline & & -225.95 & -548.66 & \\
\hline \multirow{2}{*}{ Caña } & 6262.48 & 5597.40 & 5536.05 & \multirow{2}{*}{-726.43} \\
\hline & & -665.08 & -61.35 & \\
\hline \multirow{2}{*}{ Citrus } & & 873.37 & 1102.59 & \multirow{2}{*}{+1102.59} \\
\hline & & +873.37 & +229.22 & \\
\hline \multirow{2}{*}{ Arándano } & & & 329.9 & \multirow{2}{*}{+329.9} \\
\hline & & & +329.9 & \\
\hline \multirow{2}{*}{ Poblados } & 55.19 & 72.85 & 123.74 & \multirow{2}{*}{+68.55} \\
\hline & & +17.66 & $\begin{array}{r}+50.89 \\
\end{array}$ & \\
\hline
\end{tabular}

$\mathrm{Rb}$ que oscila entre 3 y 5 , por lo que el valor promedio clasifica a la subcuenca como subcuenca de montaña sin demasiada dependencia estructural (Strahler, 1974). Este parámetro está relacionado con picos de crecida en tiempos más cortos. La mayor alteración se produce entre los cursos de orden 1-2 y 4-5, donde el desarrollo de las líneas de escorrentía se debe, fundamentalmente, al cambio de pendientes y a la litología. La Relación de longitud Rl (Horton, 1945) señala valores altos para los cauces entre los órdenes 4-5, afianzando así la conclusión obtenida para los valores de $\mathrm{Rb}$, no así entre los órdenes 1-2. Esto puede estar relacionado, principalmente, con la configuración topográfica del área. Sala y Gay (1981) expresan que valores bajos de $\mathrm{Rl}$ indican mayor energía concentrada bruscamente (caso entre los órdenes 3-4 y 5-6), mientras que valores altos indican una concentración paulatina de caudales en el colector principal (caso entre los órdenes 1-2, 2-3 y 4-5).

La Extensión media del escurrimiento superficial hasta el cauce más cercano (E) es de $80 \mathrm{~m}$. La densidad de drenaje Dd (Strahler, 1964) cuantifica el grado de desarrollo del sistema hidrográfico. Si la red de drenaje está bien desarrollada el

Tabla 2. Valores de CN (Curva Número) para las Condiciones Precedentes de Humedad CPH II y CPH III en la subcuenca de aporte al tramo meandriforme A-B.

\begin{tabular}{|l|c|c||} 
& \multicolumn{2}{|c|}{$\begin{array}{c}\text { Condición Precedente de Humedad } \\
\text { (CPH) }\end{array}$} \\
\hline Cobertura & II & III \\
\hline Monte & CN 52 & CN 72 \\
\hline Caña & CN 71 & CN 88 \\
\hline Citrus & CN 80 N 94 \\
\hline Arándano & CN 89 & CN 97 \\
\hline Urbano & CN 92 & CN 98 \\
\hline
\end{tabular}


escurrimiento superficial alcanzará los cursos fluviales con rapidez. El desarrollo de la red de drenaje se encuentra asociado con la magnitud de las pendientes, la litología y las condiciones climáticas. El valor de densidad $3.23 \mathrm{~km} / \mathrm{km}^{2}$ señala un sustrato de moderada permeabilidad y pendientes fuertes que favorecen el escurrimiento superficial, con alta capacidad de respuesta ante una precipitación intensa. El coeficiente de almacenamiento RHO (Horton, 1945) permite evaluar la capacidad de almacenamiento y el valor promedio obtenido (0.59) indica moderada capacidad de almacenamiento.

Tanto el Índice de Alargamiento Io (2.81) como el Coeficiente de compacidad Kc (1.92) afirman que la subcuenca es elongada y el Factor forma Ff (0.17) constata que es muy alargada. La caracterización de una cuenca en función de los índices Io, $\mathrm{Kc}$ y $\mathrm{Ff}$ tiene una relación directa con el tiempo de concentración del escurrimiento superficial en los cauces principales. Por ejemplo, para una lluvia de igual intensidad, en una cuenca redondeada el Kc varía alrededor de uno y el tiempo de concentración es bajo. Por el contrario, en cuencas alargadas toma valores cercanos a dos o mayores, con tiempos de concentración más altos. En este caso la subcuenca en estudio se clasifica como muy elongada, por lo que tendría un tiempo de concentración alto, bajo potencial de crecientes y baja producción sostenida de caudales. El tiempo de concentración calculado es de 4.71 hs.
Tabla 3. Incrementos (+) en la escorrentía obtenidos por el Método de la Curva Número en el período 1876-2017, para las Condiciones Precedentes de Humedad CPH II (normal) y CPH III (húmedo).

\begin{tabular}{|c|c|c|c|c|c|}
\hline & \multicolumn{4}{|c|}{ Años } & \multirow[b]{2}{*}{ Incremento total } \\
\hline & 1876 & 1975 & 2005 & 2017 & \\
\hline \multirow{2}{*}{ Escorrentía (mm) para CPH II } & 3.01 & 6.29 & 6.70 & 7.35 & \multirow{2}{*}{+4.34} \\
\hline & & +3.28 & +0.41 & +0.65 & \\
\hline \multirow{2}{*}{ Escorrentía (mm) para CPH III } & 18.63 & 25.93 & 26.54 & 27.47 & \multirow{2}{*}{+8.84} \\
\hline & & +7.30 & +0.61 & +0.93 & \\
\hline
\end{tabular}

Aunque, el Índice de circularidad (Ic) arroja un valor de 0.27 , lo que la clasifica como ovalada. En ese caso tendría moderado potencial de crecientes y alta producción sostenida de caudales. El coeficiente de torrencialidad Ct (5.53) revela una subcuenca de moderada torrencialidad. En el cálculo de este coeficiente interviene el número de cauces de primer orden, cuyo porcentaje es del $81 \%$ del total de cauces, por lo que indica la presencia de un sustrato poco permeable o impermeable próximo a la superficie en la zona montañosa. Hacia el piedemonte se incrementaría la permeabilidad por la presencia de suelos de mayor espesor. No obstante, los cultivos han alterado las propiedades físicas de estos suelos incentivando el predominio del escurrimiento sobre la infiltración. Las Figuras 12 y 13 muestran las pendientes de la subcuenca.

Las pendientes del 10\% al 70\% se encuentran en las laderas del área montañosa ocupando la mayor superficie (10588.4 ha). En esta zona existen también pendientes que oscilan entre $0 \%$ y $10 \%$, principalmente en los valles de fondo plano, terrazas fluviales y superficies cumbrales

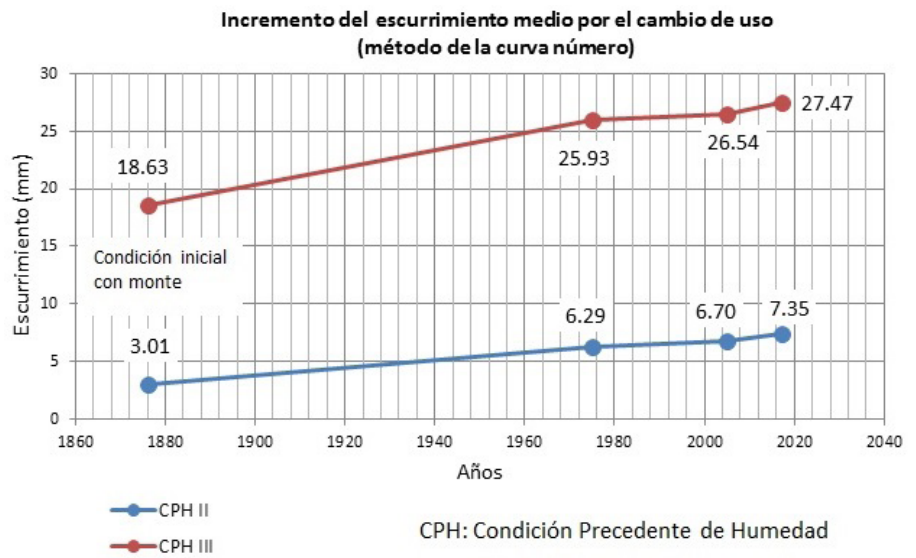

Figura 10 Incremento del escurrimiento superficial calculado por el método de la curva número, para las Condiciones Precedentes de Humedad CPH II y CPH III. En los cálculos y la confección de la gráfica se tuvo en cuenta los valores de las Tablas 1 y 2. 
aplanadas, ocupando una superficie de 5213.92 ha. En el piedemonte, zona en que se observan los mayores procesos de degradación, las pendientes fluctúan entre $0 \%$ y $10 \%$, ocupando una superficie de 5407.37 ha. La Figura 13 muestra cómo disminuyen las áreas con menores pendientes $(0-2 \%)$ al incrementarse la altura y el marcado contraste topográfico entre el piedemonte y las laderas. El área que ocupa la zona montañosa y las elevadas pendientes explican, en gran medida, la torrencialidad que manifiesta la cuenca alta y su influencia sobre los procesos erosivos.

\subsection{ANÁLISIS DEL PROGESO DE MEANDRIZAGIÓN}

La Figura 14 muestra la evolución del cauce principal del río Seco durante el lapso temporal 19722017, desde la Ruta Nacional 38 hasta la Ruta Nacional 157. Puede observarse que el mayor proceso de meandrización se ha manifestado entre la nueva traza de Ruta Nacional 38 y la localidad de La Tuna.

A partir de esta localidad se observan meandros, pero éstos se encuentran mucho más separados, muestran menor movilidad horizontal y el cauce está más encajado en los sedimentos del Cuaternario. Por otro lado, la Figura 15 muestra
Tabla 4. Parámetros morfométricos de la subcuenca de aporte al tramo menadriforme.

\begin{tabular}{|c|c|c|c|c|c|c|c|}
\hline \multicolumn{2}{|c|}{ Cauces } & $\mathrm{N}^{0}$ & $\begin{array}{c}\text { Longitud } \\
(\mathrm{km})\end{array}$ & $\begin{array}{l}\text { Long med. } \\
(\mathrm{km})\end{array}$ & $\mathrm{Rb}$ & $\mathrm{Rl}$ & RHO \\
\hline \multirow{6}{*}{$\dot{Z}$} & 1 & 1196 & 356.24 & 0.30 & 5.59 & & \\
\hline & 2 & 214 & 169.36 & 0.84 & 4.65 & 2.81 & 0.50 \\
\hline & 3 & 46 & 94.05 & 2.04 & 4.18 & 2.44 & 0.52 \\
\hline & 4 & 11 & 27.43 & 2.49 & 5.50 & 1.22 & 0.29 \\
\hline & 5 & 2 & 22.51 & 11.26 & 2.00 & 4.51 & 0.82 \\
\hline & 6 & 1 & 18.62 & 18.62 & & 1.65 & 0.83 \\
\hline \multicolumn{2}{|c|}{ Total } & 1470 & 698.22 & & & & \\
\hline $\mathrm{Fr}$ & $\mathrm{Dd}$ & E & Io & $\mathrm{Ct}$ & $\mathrm{Kc}$ & $\mathrm{Ff}$ & Lo \\
\hline 6.8 & 3.23 & $80 \mathrm{~m}$ & 2.81 & 5.53 & 1.92 & 0.62 & $150 \mathrm{~m}$ \\
\hline
\end{tabular}

el tramo nueva Ruta Nacional 38 - La Tuna (A-B), donde las pendientes del cauce varían entre $0.2 \%$ y $2 \%$, en el cual se observa una elevada movilidad transversal del cauce. Presenta meandros abandonados, principalmente en la margen izquierda, donde se encuentran lagunas y pantanos cubiertos de vegetación acuícola y de monte; éstos son ocupados, parcialmente, por la corriente durante las crecidas estacionales.

El material del lecho es, en mayor medida, de arena media a fina y la altura media de los márgenes es de $2 \mathrm{~m}$. La planicie aluvial circundante es marcadamente irregular con numerosos paleocanales de formas sinuosas que se relacionan de manera estrecha con el cauce principal y, en muchos casos, ocupan cotas más elevadas que el lecho principal.

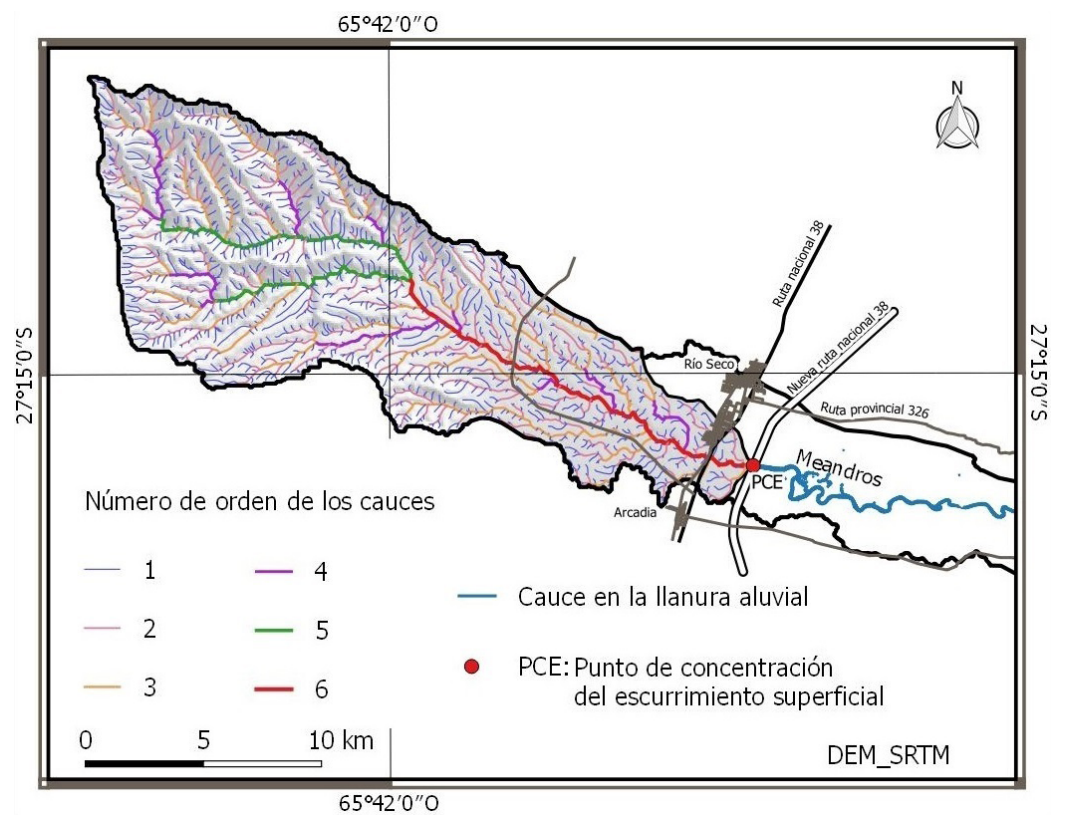

Figura 11 Mapa hidrogeomorfológico de la subcuenca de aporte. El PCE (Punto de Concentración del Escurrimiento Superficial) se encuentra sobre el cauce principal, de orden 6 . Se observa la estrecha relación espacial que mantiene con los meandros en estudio. 
La movilidad del cauce en sentido horizontal tiene dos extremos muy marcados. Uno de ellos es la máxima expansión hacia el norte (1400 m), que se presentó en los meandros abandonados de la margen izquierda en el año 2002, mientras que el meandro de la margen derecha se desplazó 1000 $m$ hacia el sur en el año 2017. El desplazamiento total entre ambos extremos fue de $2400 \mathrm{~m}$.

La curva de sinuosidad e imágenes satelitales de los años 1972, 1984, 2002, 2011 y 2017 de la Figura 16 muestran cómo se ha incrementado la sinuosidad del cauce desde 1972 (1.25) hasta 2002, cuando alcanza su valor máximo (2.35). A partir de 2002 se produjeron cortes en los meandros por desborde (chute cutoff) y por tangencia (neck cutoff), lo que produjo la progresiva disminución de la sinuosidad hasta alcanzar el valor de 1.31 en 2011. Los puntos rojos sobre la línea de sinuosidad indican las fechas aproximadas en las cuales se iniciaron los procesos de cortes de los meandros, mientras que los verdes, las fechas aproximadas en las que el flujo de inundación modeló un nuevo cauce, ya sea por erosión uniforme sobre una traza existente más rectilínea (paleocauce) y de menor longitud que el arco del meandro o por erosión retrocedente desde el extremo de aguas abajo de la curva. Posteriormente, y a partir de 2011, comenzó a incrementarse nuevamente la sinuosidad del cauce hasta alcanzar el valor de 1.74 en 2017.
Las imágenes satelitales secuenciales de la Figura 16, seleccionadas para mostrar los cambios en el diseño del cauce, exponen el orden temporal en que se produjeron los cortes de canal, siendo M1 el corte más antiguo y así sucesivamente hasta el corte M5 (el corte más reciente). Muestran, además, la ubicación de los meandros y la migración que ha tenido el cauce hacia el sur por erosión lateral, tomando como referencia una línea recta imaginaria trazada entre los puntos extremos del tramo A-B. En las imágenes de los años 1972 y 1984 el talweg tiene una relación equidistante con respecto a la línea de referencia, excepto por la curva del cauce ubicado a la izquierda. En 2002, cuando ocurre el mayor proceso de meandrización, la longitud del talweg es mayor al sur de dicha línea, pero todavía mantiene una relación equidistante con la misma. En la imagen de 2011, posterior a los cortes de meandros, se observa claramente que la longitud del talweg, escasamente sinuoso, es mayor al sur de la línea de referencia, y en 2017 la mayor longitud del cauce activo se encuentra por debajo de la misma.

Se comparó el hidrograma de descarga de caudal líquido, que abarca el lapso temporal mayo de 2004 a mayo de 2017 (Figura 17) registrado en la Estación Ruta Nacional 157 (Secretaría de Infraestructura y Política Hídrica de la Nación, 2018), referencia ERN 157 en Figura 6, con las imágenes satelitales Landsat multiespectrales, (combinación

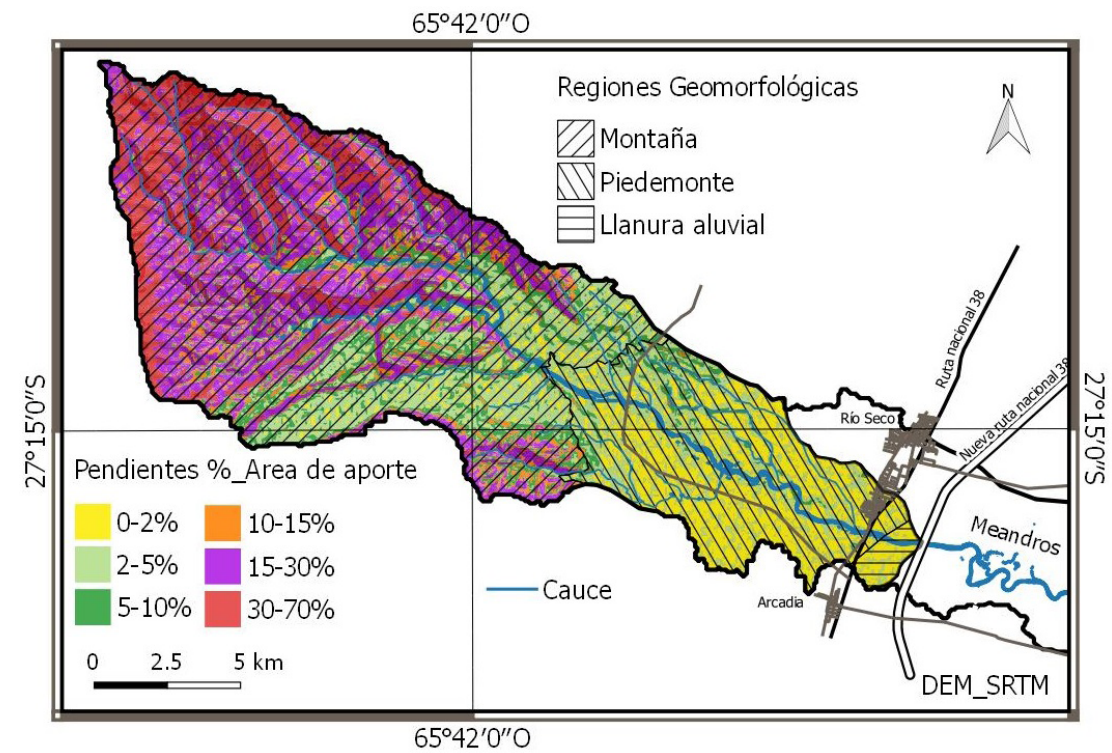

Figura 12 Porcentajes de pendientes y regiones geomorfológicas de la subcuenca de aporte al sistema de meandros. Se observa la mayor extensión superficial del área montañosa en relación a la superficie que ocupa el piedemonte. 
Land/Water: RGB: 4,5,3) utilizadas para resaltar el flujo de la corriente. Este procedimiento permitió relacionar los procesos de chute cutoff observados en el cauce con los picos de crecida de la corriente. Las modificaciones en el cauce estarían relacionadas con inundaciones relativamente altas. La conformación del canal que generó el corte del meandro M4 se produjo, aproximadamente, entre el 31/12/2006 y el 25/02/2007, aparentemente por una serie de inundaciones previas ocurridas en varias temporadas de lluvias, las cuales originaron caudales de 18 a $30 \mathrm{~m} 3 / \mathrm{seg}$. Por el contrario, el corte del meandro M5 ocurrió entre 18/12/2010 y 28/02/2011 y podría estar relacionado con eventos de inundación ocurridos en una temporada de lluvias, con caudales registrados de 72 a $104 \mathrm{~m} 3 / \mathrm{seg}$.

La Estación Ruta Nacional 157, ERN 157 en la Figura 6, registró un caudal de $173.20 \mathrm{~m} 3 / \mathrm{seg}$ en el evento de inundación ocurrido en la fecha 25/02/2016, lo que causó la destrucción del puente de Ruta Provincial 324 (Figura 7), situado en el piedemonte, aguas arriba del tramo en estudio, evidenciando con ello que el hidrograma de descarga de la cuenca tiene una alta correspondencia con los procesos en el canal.

No se encontraron hidrogramas de descarga de caudal líquido anteriores a mayo de 2004, que permitan relacionar picos de crecida con los cortes de los meandros M1, M2 y M3, ocurridos entre $27 / 02 / 2002$ y $07 / 05 / 2004$.
Sin embargo, el análisis de los datos de lluvia, aportados por la Estación Solco Yampa Ii (Secretaría de Infraestructura y Política Hídrica de la Nación, 2018) en la Figura 6, posicionada a los $27^{\circ} 10^{\prime} 43.70^{\prime \prime} \mathrm{S}-65^{\circ} 50^{\prime} 30.80^{\prime \prime} \mathrm{O}$, aguas arriba de la alta cuenca, registró eventos de lluvia de hasta $173 \mathrm{~mm}$ en ese lapso temporal. Estos habrían producido picos de inundaciones o caudales constantes que favorecieron los procesos de cortes de meandros.

La Figura 18 muestra un pluviograma de precipitaciones diarias de la Estación Solco Yampa Ii (Secretaría de Infraestructura y Política Hídrica de la Nación, 2018) e imágenes satelitales comparativas de los cortes M1, M2 y M3. El único caso por tangencia (neck cutoff) fue el del meandro M2.

Según Leopold y Wolman (1957), los trazados de los cauces fluviales se clasifican, normalmente, en tres tipos: 1) rectos, 2) meandriformes y 3) trenzados. Miall (1977) reconoció la existencia de otros diseños de cauce como es el tipo sinuoso, cuyo trazado es la transición entre el recto y el meandriforme o el anastomosado. Considera un cauce rectilíneo a aquel que tiene una sinuosidad inferior a 1.05, sinuoso cuando está comprendido entre 1.05 y 1.5 y meandriforme si su sinuosidad es mayor a 1.5 y tiene curvas alternantes que configuran un cauce con diseño serpenteante.

Tomando en consideración lo ya mencionado, se definen 5 ciclos en el tramo analizado:

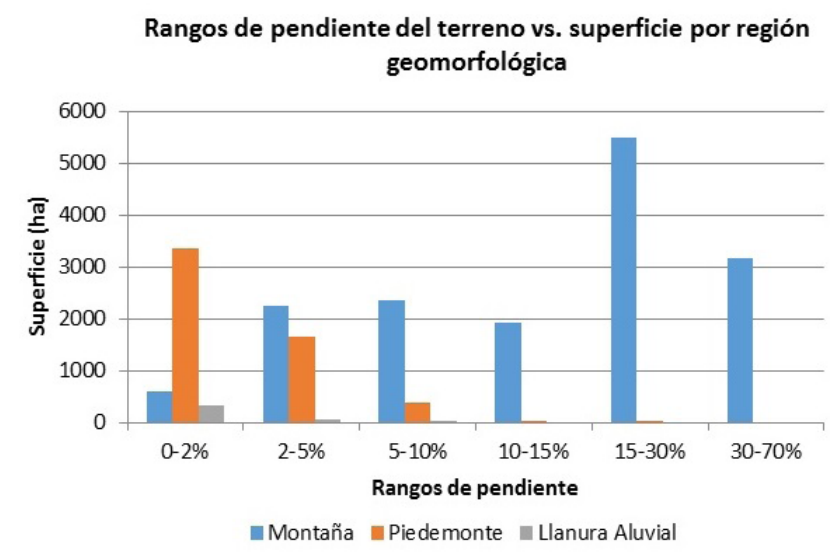

Figura 13 Rangos de pendientes por región geomorfológica. Esta gráfica esta confeccionada en función de los datos obtenidos de la Figura 12. Las mayores pendientes se encuentran en la zona montañosa ocupando además mayor superficie. Es evidente la influencia de la zona montañosa sobre el piedemonte y llanura aluvial. 
1. Años 1972 a 1984: el cauce fue sinuoso.

2. Años 1984 a 2002: el cauce fue meandriforme, con un incremento de la sinuosidad.

3. Años 2002 a 2011: el cauce fue meandriforme, con procesos de corte de meandros (chute cutoff y neck cutoff), produjeron disminución de la sinuosidad, acompañado de incisión y migración lateral del cauce hacia el cuadrante sur.

4. Años 2011 a 2013: el cauce fue sinuoso.

5. Años 2013 a 2017: se incrementó la sinuosidad y se produjo la migración lateral del cauce hacia el sur.

La Tabla 5 señala los valores máximos, mínimos y medios de los parámetros adoptados para definir la geometría de los meandros del río Seco, mientras que en la Figura 19 están graficadas las variaciones que han manifestado los valores medios del radio de curvatura, y la longitud y amplitud de onda de los meandros. Durante el lapso temporal 1984-2002 el cauce tuvo un decrecimiento de la longitud de onda, un incremento de la amplitud de onda y prácticamente sin variaciones en el radio de curvatura de los meandros. Por el contrario, en el lapso 2002-2017 se han manifestado cambios muy profundos en el diseño del cauce que han modificado notablemente la longitud y la amplitud de onda de los meandros, con una fuerte correlación entre ambos parámetros, por lo que la variación de uno de ellos tuvo efectos sobre el otro. El radio de curvatura se ha modificado en menor medida, pero también ha sido influenciado por la variación de los parámetros anteriores. Los procesos de cortes de meandros chute cutoff son las manifestaciones más sobresalientes en la evolución del río Seco. Dichos procesos incentivaron la migración del cauce principal hacia el sur, dejando cauces abandonados en forma de arcos o bucles en la margen izquierda. En ellos se encuentran depresiones con suelos saturados o inundados, donde se desarrolla vegetación acuática.

Durante las crecientes, el poder erosivo de la corriente amplía las curvas de los meandros, produciendo la migración de los mismos. Este proceso incluye incisiones en las márgenes cóncavas de los meandros, que, impulsadas por el flujo en exceso, produce desbordes, favorecidos por las depresiones del terreno, antiguos cauces de la llanura aluvial o meandros abandonados, en los cuales se encauza el flujo excedente. Las crecientes modifican este ambiente y cambian repentinamente el diseño del sistema fluvial durante las inundaciones. En la

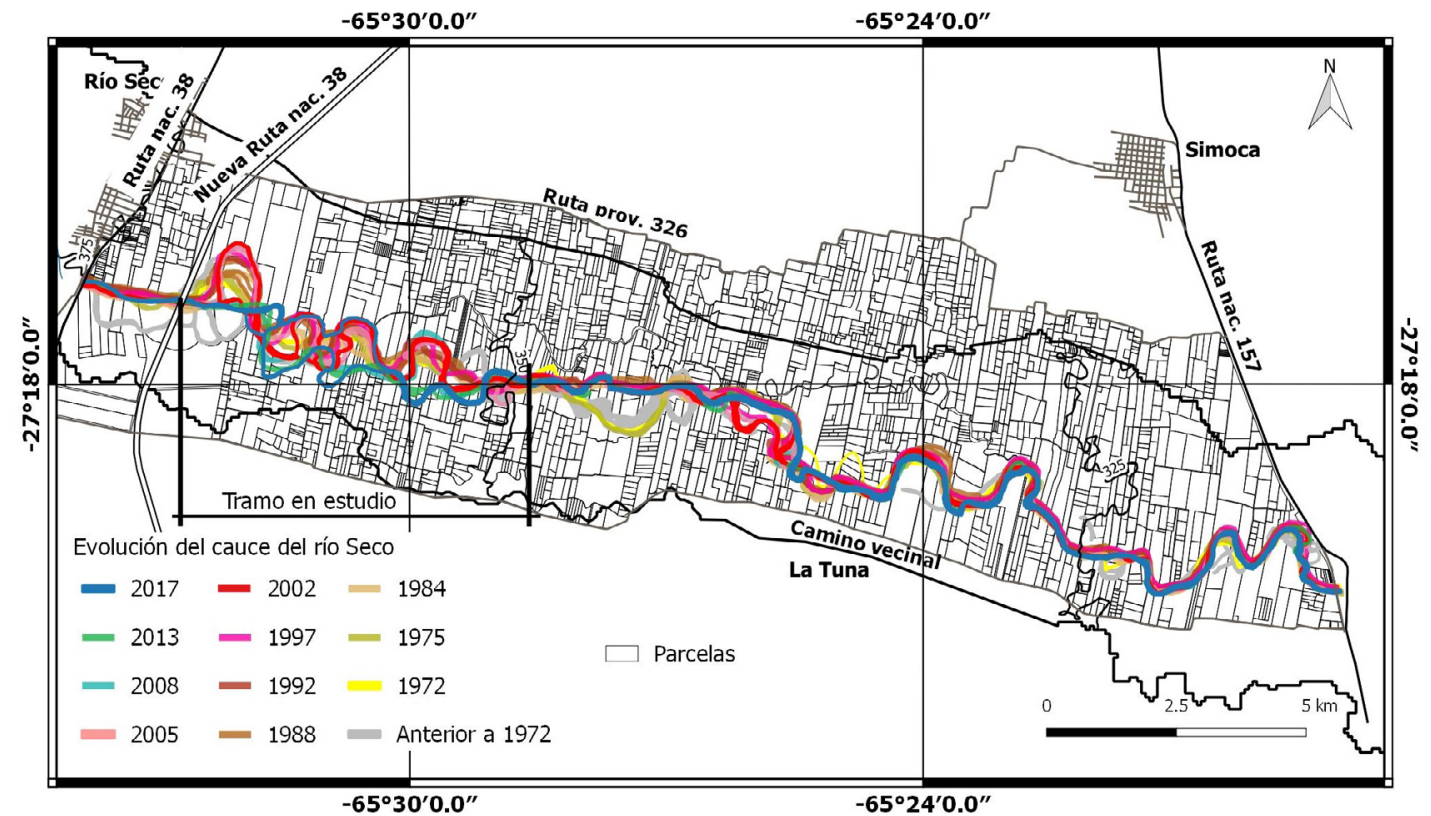

Figura 14 Evolución del cauce del río Seco en el lapso 1972-2017, entre la ruta nacional 38 y la ruta nacional 157 . El tramo en estudio muestra un elevado proceso de migración lateral del cauce. 
imagen Sentinel 2B del 9 de marzo de 2016 (Figura 20), se observa un evento de crecida que causó el desborde de la corriente principal en dos brazos: uno de ellos inundó los arcos de dos meandros abandonados de la margen izquierda hasta unirse con la corriente principal aguas abajo; el otro se encauzó en un tramo de canal de menor curvatura, acortando la trayectoria del meandro activo de la margen derecha, pero la corriente principal siguió la traza del bucle del meandro. En la temporada de aguas bajas, como se observa en la imagen Landsat 8 de la fecha 18/10/2017 (Figura 16), la corriente sigue encauzándose por los arcos de los meandros abandonados de la margen izquierda (posiblemente como consecuencia del desborde del cauce producido por la inundación del 9 de marzo de 2016) y por los meandros más recientes de la margen derecha, sin que se haya producido un corte efectivo del meandro como consecuencia de la ya mencionada inundación.

\subsection{PÉRDIDAS DE TIERRAS AGRÍCOLAS}

Los desplazamientos del cauce del río Seco han provocado importantes pérdidas de tierras que estaban dedicadas, desde antaño, al cultivo de la caña de azúcar por los procesos de desbordes y erosión lateral de cauces, los cuales cambian la orientación de la corriente, erosionando las barrancas compuestas de sedimentos no consolidados (arenas, limos y gravas), de elevada susceptibilidad a los procesos erosivos. Asimismo, produjeron la pérdida de 370.68 ha de suelos productivos, por lo que el volumen de suelo removido y transportado por las corrientes fue de $7413600 \mathrm{~m}^{3}=7.41 \mathrm{hm}^{3}$, con una profundidad media de las barrancas de 2 $\mathrm{m}$, afectando así, total o parcialmente, 94 parcelas de productores cañeros minifundistas. La Figura 21 esquematiza de manera detallada los espacios fluviales para los años 1984 y 2017. En las imágenes satelitales se observan sectores que fueron afectados por la corriente y luego abandonados. Los mismos fueron ocupados reiteradamente por los cultivos, con el riesgo de ser inundados nuevamente por las crecidas del río.

La figura 22 muestra los hidrogramas de caudales líquidos y sólidos (gruesos y finos) desde mayo de 2004 a diciembre de 2017. Estas mediciones fueron realizadas en la Estación Ruta Nacional 157, ERN 157 en la Figura 6 (Secretaría de Infraestructura y Política Hídrica de la Nación, 2018). El registro de caudal líquido del 16 de febrero de 2015 (referencia 4 en la Figura 22) fue de 112.74 $\mathrm{m}^{3} / \mathrm{seg}$. Este caudal transportó $118.73 \mathrm{~kg} / \mathrm{seg}$ de caudal sólido grueso y $1435.09 \mathrm{~kg} / \mathrm{seg}$. de caudal sólido fino.

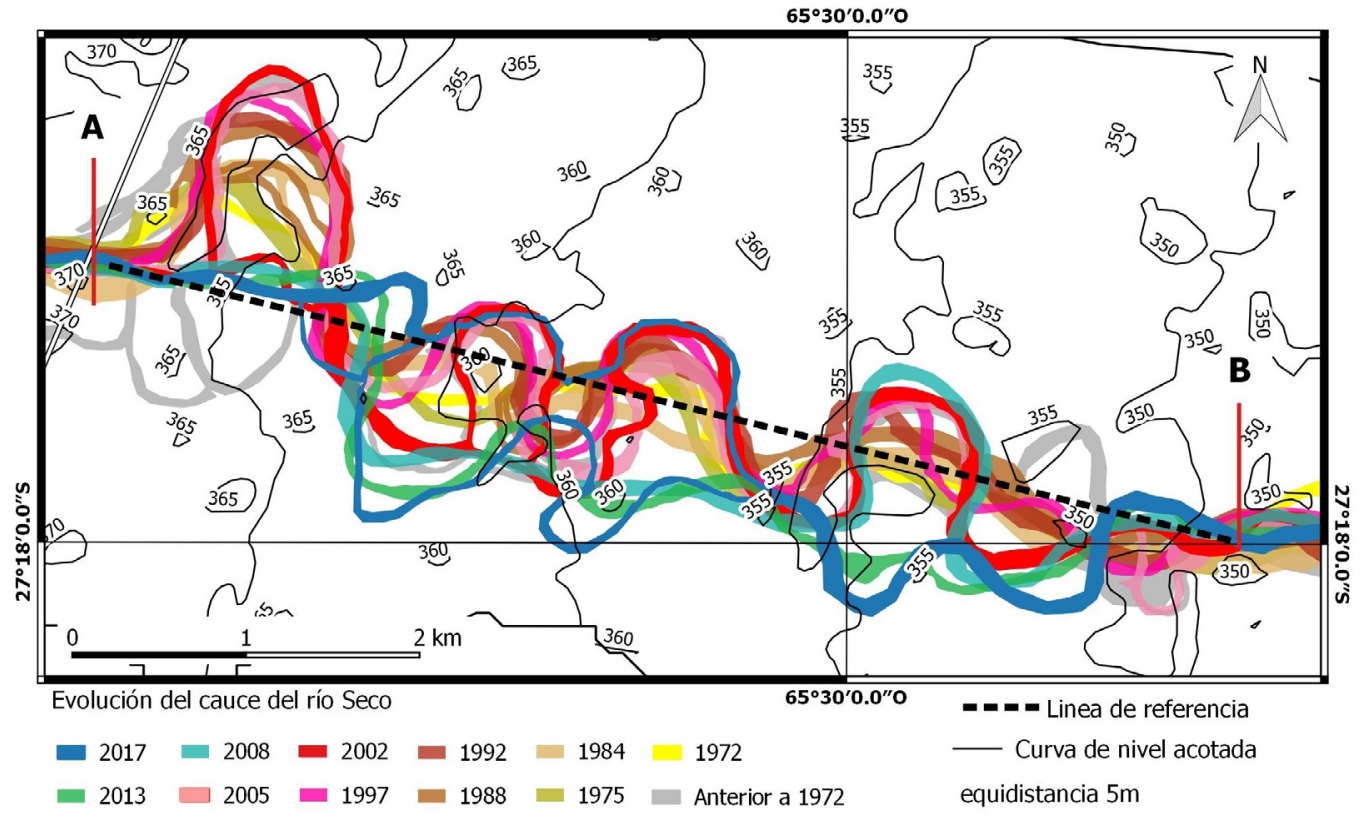

Figura 15 Evolución del cauce del río Seco en el lapso 1972-2017, tramo A-B en estudio. 

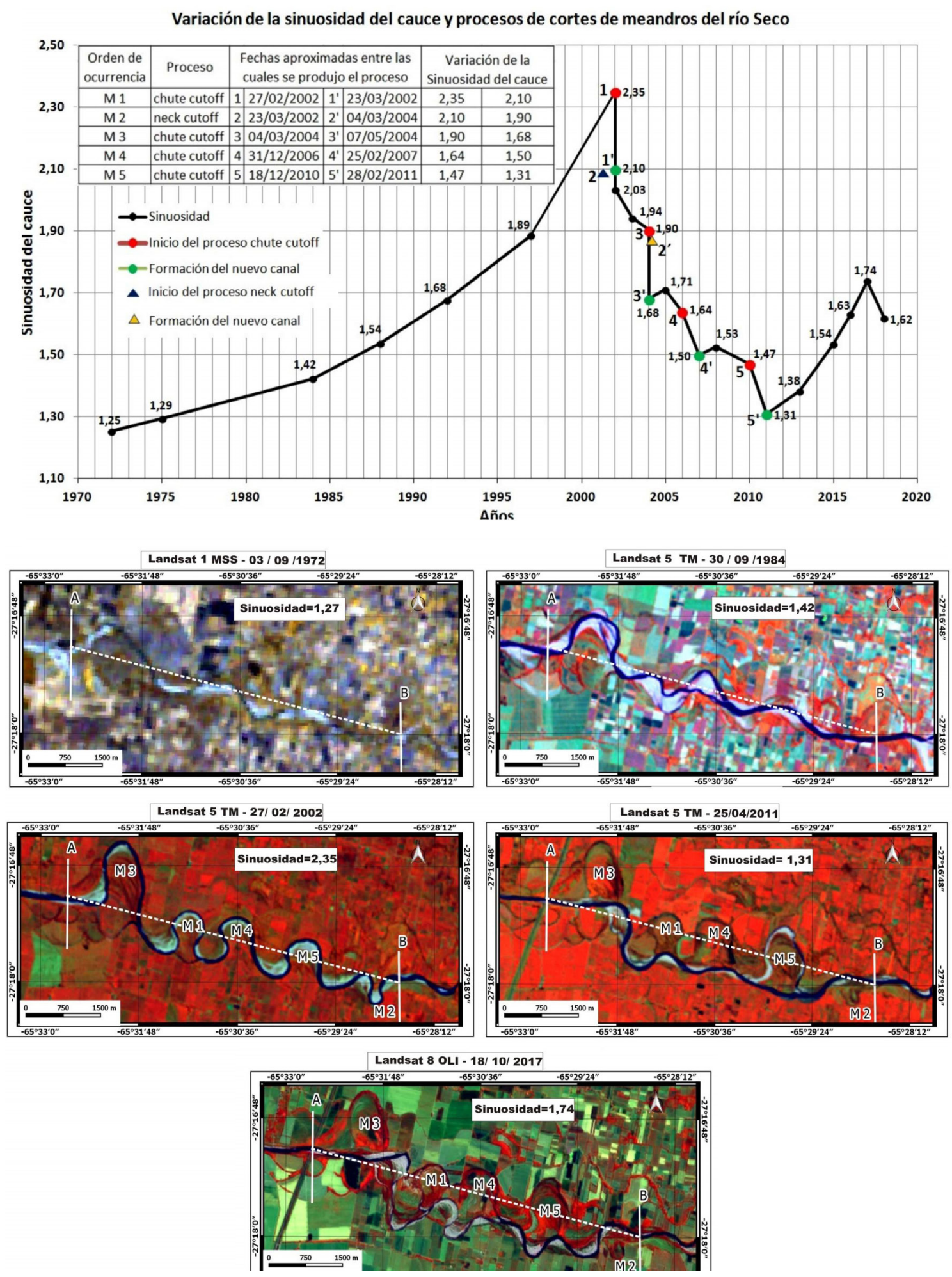

Figura 16 Curva de sinuosidad del cauce el río Seco e Imágenes satelitales Landsat en el tramo A-B para el lapso temporal 1972-2017. Los números 1,2,3,4 y 5 sobre la curva y la tabla incorporada indican las fechas aproximadas en las que se iniciaron los cortes de meandros y los números 1', 2', 3',4' y 5' las fechas aproximadas en que se conformó el nuevo canal. La línea de referencia entrecortada de color blanco evidencia la progresiva migración del cauce hacia el sur por los procesos de corte de meandros y erosión lateral. Las referencias M1, M2, M3, M4 y M5 indican el orden en que ocurrieron los cortes. 
En cambio, la máxima creciente registrada el 25 de febrero de 2016 (referencia 5) que generó la destrucción del puente sobre el piedemonte (caudal liquido: $173.2 \mathrm{~m} 3 / \mathrm{seg}$ ); se observa que los valores de caudal solido grueso $(26.72 \mathrm{~kg} / \mathrm{s})$ y fino $(188.20$ $\mathrm{kg} / \mathrm{s}$ ) son mucho menores que los del evento de crecida del 16 de febrero de 2015. La comparación de estos valores indica que un aumento de caudal líquido no va acompañado necesariamente de un incremento del caudal sólido ni a la inversa. Para las fechas 14/12/2007, 25/02/2010 y 24/02/2011 (referencias 1,2 y 3 en la Figura 22) se observa una cierta correlación entre las variables, mientras que entre las fechas 1-2 y 3-4 se registraron picos de caudales líquidos que reflejan menor caudal de sedimentos finos y gruesos.
El análisis de esta información hidrológica manifiesta la complejidad de la respuesta hidrogeomorfológica y de los procesos dominantes en la producción de sedimentos de la subcuenca de aporte. Dichos procesos pueden ocurrir de manera simultánea en diferentes áreas de la subcuenca o aislados de acuerdo a la distribución de un evento de lluvia.

Esta condición evidencia que no existe una relación directa entre el caudal líquido y el volumen de sólidos transportados, dado que los aportes de sedimentos a los cauces estarían controlados por las condiciones naturales y antrópicas de las áreas receptoras de la precipitación y del escurrimiento, y de las generadoras de sedimentos y de deposición.

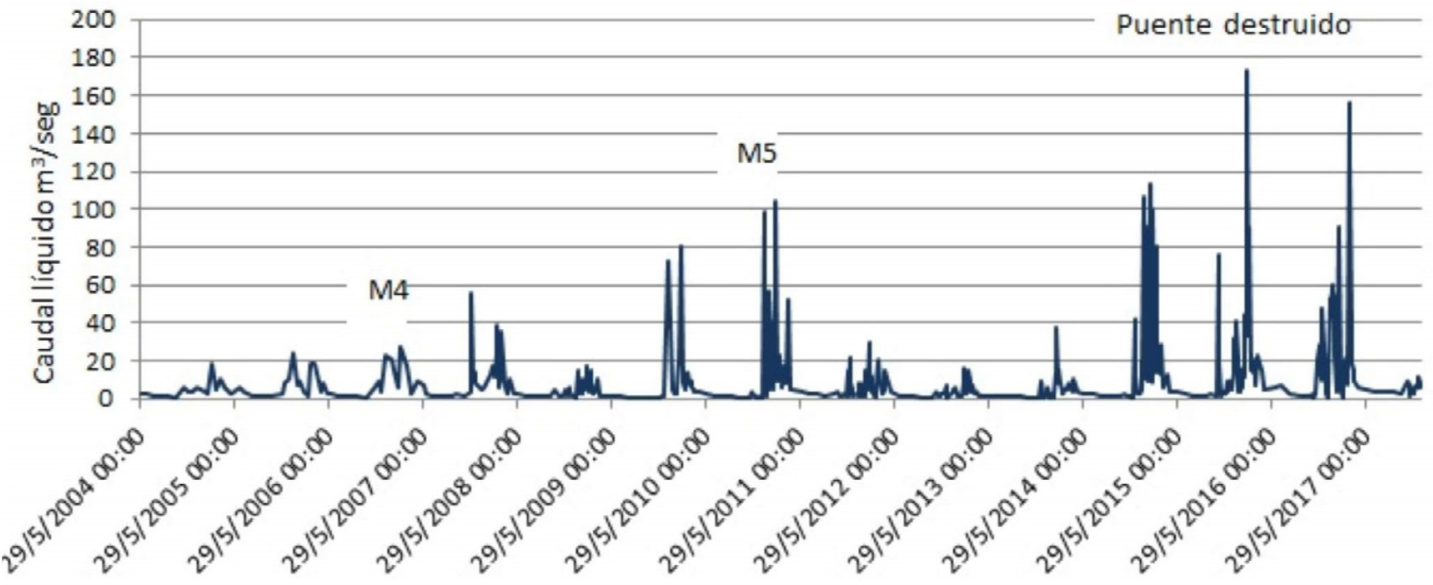

M4 Landsat 5 TM - 25/02/2007
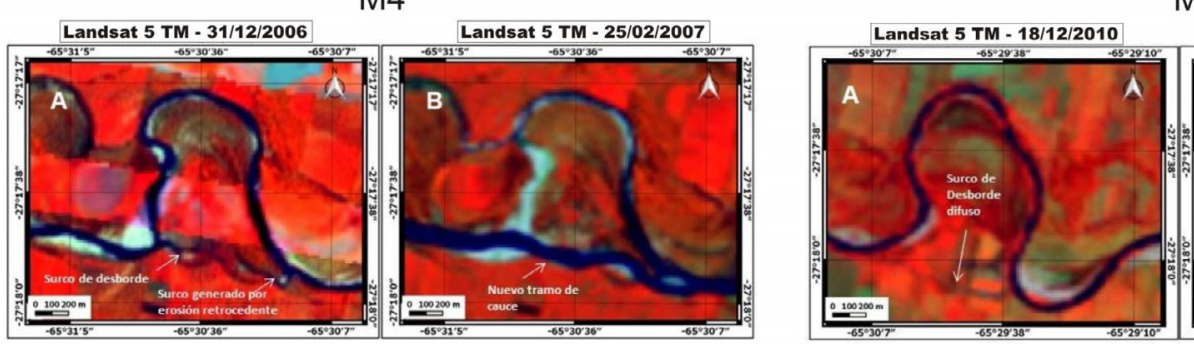

M5

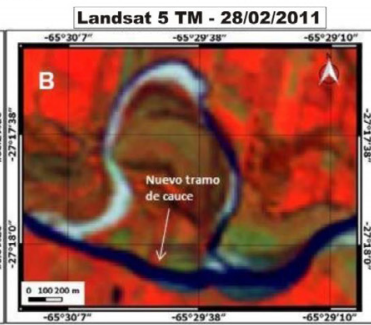

Figura 17 Hidrograma de descarga líquida de la cuenca del río Seco, registrado en la estación Ruta Nacional 157 (27020’10.23” S; $65^{\circ}$ 19' 02.64"), aguas abajo del tramo meandriforme. Las referencias M4 y M5 relacionan los picos de descarga con los cortes por desborde (chute cutoff) observados en las imágenes satelitales Landsat5 TM. Se muestra el elevado pico de descarga (173.20 m3/seg), que produjo la destrucción del puente sobre el río Seco el 25 de febrero de 2016. Corte M4: En la escena M4A (31/ 12/2006) se observa un surco de desborde en la curva aguas arriba del meandro y un surco de erosión retrocedente en la curva aguas abajo. En la escena M4B (25/02/ 2007) se observa el nuevo tramo de cauce labrado sobre la traza del surco de desborde y de erosión retrocedente. Corte M5: En la escena M5A (18/ 12/ 2010) se observa un surco de desborde difuso y en la escena M5B (28/02/2011) la conformación del nuevo canal siguiendo la traza del surco de desborde. 


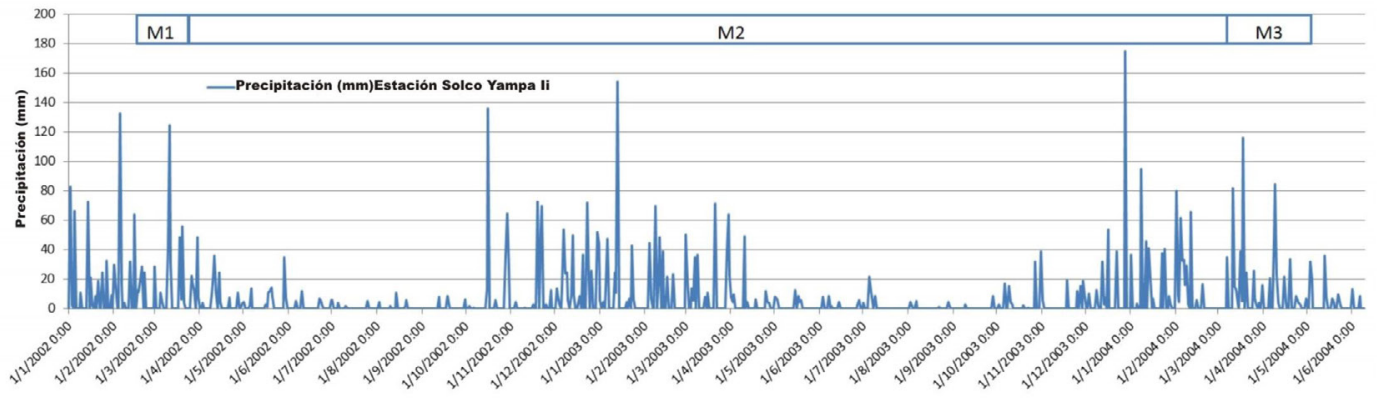

M1
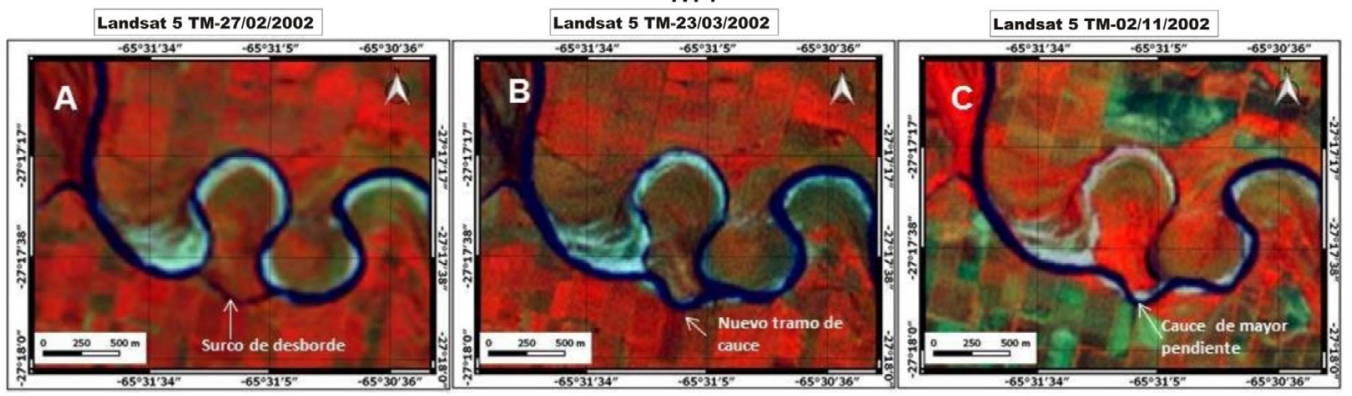

M2
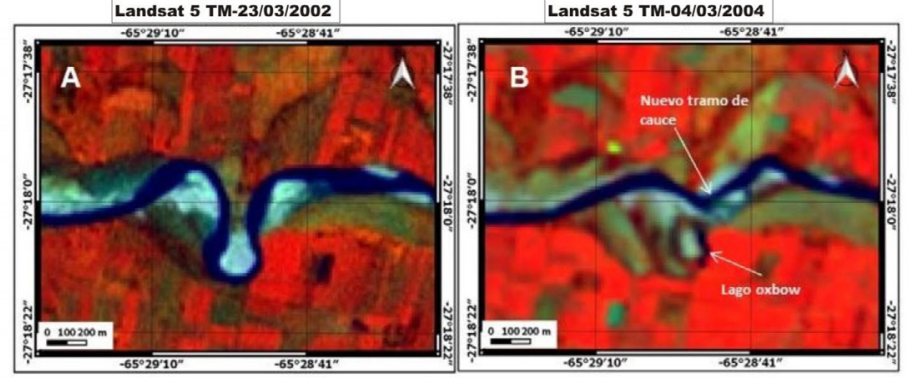

M3

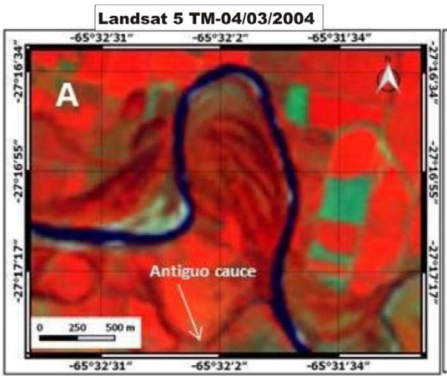

Landsat 5 TM-07/05/2004

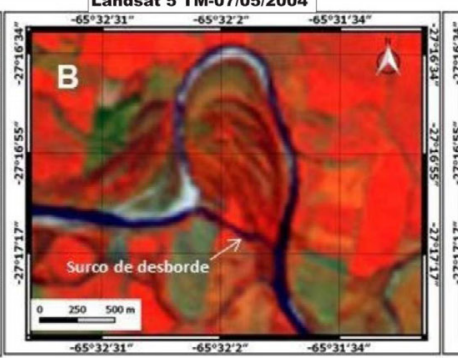
Landsat 5 TM-01/12/2004

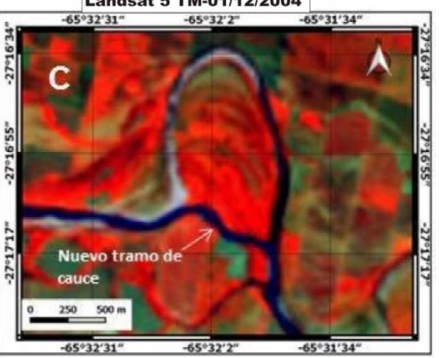

Figura 18 Precipitaciones diarias registradas en la Estación Meteorológica Solco Yampa li (2710’43.70”S, 6550’30.80”O). Las referencias M1, M2 y M3 relacionan los eventos de Iluvia con los cortes de meandros(chute cutoff y neck cutoff). Corte M1 (chute cutoff). En la escena M1 A (27/02/ 2002) se observa un surco de desborde, que podría ser parte de un antiguo cauce meandriforme. En la escena M1 B (23/ 03/ 2002) la corriente principal de un evento de inundación se ha encauzado siguiendo la traza del antiguo canal, modificando su ancho; pero el meandro conduce todavía un porcentaje de la inundación. En la escena M1C (02/ 1 1 / 2002) posterior a la inundación, el meandro fue abandonado y la corriente principal se concentra en el canal de corte. Las escenas M2A (23/ 02/ 2002) y M2B (04/ 03/ 2004) muestran el único caso de corte por tangencia (neck cutoff). En M2A el cauce presenta una elevada sinuosidad. La distancia que separa ambas orillas (cuello) de las curvas adyacentes es de $60 \mathrm{~m}$ aproximadamente. En M2B las curvas del cauce se interceptaron por tangencia, acortando el cauce y dejando un bucle abandonado (oxbow lake), o lago en forma de herradura. En estas formas se concentra el escurrimiento superficial formando lagunas o pantanos. Corte M3 (chute cutoff). En la escena M3A (04/ 03/ 2004) se observa un antiguo cauce que desemboca aguas abajo de la curva del meandro y la escena M3B (07/ 05/ 2004) muestra un surco de desborde por el cual se encauza la corriente principal. En la escena M3C (01/ 12/ 2004), se presenta un evento de inundación que amplio el surco de desborde estableciéndolo como cauce principal. 
Otro factor a considerar es que el escurrimiento superficial en áreas permeables se inicia luego de que el suelo es saturado por las aguas de lluvias, por lo que el aporte de sedimentos tendrá un retardo a partir del inicio de la lluvia.

\section{Discusión}

El análisis de los cambios morfológicos de los cauces fluviales es un tema muy desarrollado en geomorfología fluvial, pero la interpretación de dichos cambios, identificando y valorando las causas que los originaron, constituye una labor muy compleja (Schumm, 1971). Sin embargo, Schumm (1977) consideró que las modificaciones en el diseño de drenaje de un sistema fluvial pueden ser influidas tanto por el caudal líquido como por la cantidad o tipo de carga. Otros factores, tales como cambios de la cubierta vegetal, la erosión de los suelos, la mayor precipitación total, cambios en el régimen de precipitaciones, cambios en el régimen de escurrimiento, mayores lluvias individuales, mayor frecuencia de tormentas y humedad del suelo (Dury, 1965) también influyen sobre estas modificaciones.

$\mathrm{Al}$ plantearse un estudio que intente descifrar los mecanismos que actúan sobre las modificaciones en los cauces se suceden una serie de limitaciones, tales como la falta o escasez de información hidro-meteorológica accesible o disponible (precipitación, niveles de cauces y caudales líquidos y sólidos), por lo que es más o menos dificil caracterizar las variables con la pretendida exactitud y resolución. Una de las variables difíciles de caracterizar está relacionada con los registros de precipitaciones (intensidad, recurrencia y extensión del evento), así como con el volumen de escurrimiento que estas generan, teniendo en cuenta las características del ambiente físico, tales como la topografía, el diseño de drenaje, huellas de fenómenos anteriores y el cambio de uso de los suelos. La información teledetectada disponible en la red de las últimas décadas ha sido de fundamental importancia para este estudio, ya que son una fuente confiable al momento de monitorear los cambios en los cauces y la cobertura del terreno a través del análisis multitemporal.

El proceso de degradación del área de aporte, producido por el inadecuado manejo y explotación de los suelos cultivados desde años anteriores, que trascienden al periodo analizado, ha tenido una notable influencia en los cambios morfológicos del cauce. Estos suelos han soportado labranzas que han alterado sus propiedades fisicas para posibilitar el desarrollo de los cultivos. Su degradación estructural se observa tanto en la superficie como debajo del manto arado, donde se forman capas

Relación entre radio de curvatura, amplitud y longitud de onda de los meandros del río Seco

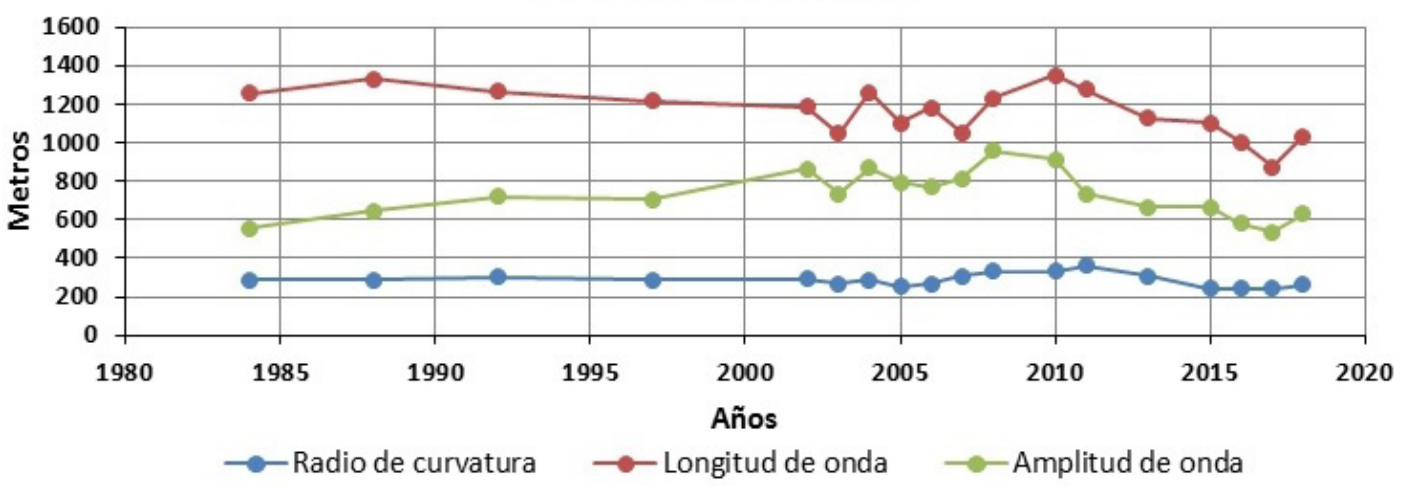


Tabla 5. Parámetros adoptados para analizar la geometría de los meandros.

\begin{tabular}{|c|c|c|c|c|c|c|c|c|c|c|c|c|c|c|c|}
\hline \multirow{2}{*}{ Año } & \multicolumn{3}{|c|}{ Radio de curvatura } & \multicolumn{3}{|c|}{ Longitud de onda } & \multicolumn{3}{|c|}{ Amplitud de onda } & \multicolumn{3}{|c|}{ Ancho del canal activo } & \multirow{2}{*}{$\begin{array}{c}\text { Sinuosidad } \\
\text { Leopold y } \\
\text { Wolman (1957) }\end{array}$} & \multirow{2}{*}{$\begin{array}{l}\text { Clasificación } \\
\text { Miall (1977) }\end{array}$} & \multirow{2}{*}{$\begin{array}{c}\text { Lapso } \\
\text { Temporal }\end{array}$} \\
\hline & Máximo & Mínimo & Media & Máximo & Mínimo & Media & Máximo & Mínimo & Media & Máximo & Mínimo & Media & & & \\
\hline 1972 & & & & & & & & & & 100.00 & 50.30 & 79.94 & 1.25 & Sinuoso & \multirow{3}{*}{ 1972-1984 } \\
\hline 1975 & & & & & & & & & & 120.00 & 45.00 & $8 ., 45$ & 1.29 & Sinuoso & \\
\hline 1984 & 469.40 & 112.30 & 287.52 & 1568.68 & 948.43 & 1254.87 & 905.49 & 269.73 & 553.54 & 131.00 & 56.00 & 94.13 & 1.42 & Sinuoso & \\
\hline 1988 & 424.67 & 198.34 & 287.43 & 1535.70 & 1022.33 & 1328.72 & 1125.78 & 423.77 & 644.17 & 92.65 & 55.87 & 72.80 & 1.54 & Meandriforme & \multirow{4}{*}{ 1984-2002 } \\
\hline 1992 & 423.70 & 180.80 & 300.32 & 1726.09 & 850.98 & 1265,16 & 1101.40 & 377.25 & 720.94 & 96.41 & 62.03 & 76.27 & 1.68 & Meandriforme & \\
\hline 1997 & 370.00 & 235.11 & 288.01 & 1774.41 & 853.23 & 1214.44 & 1385.46 & 289.08 & 702.82 & 70.93 & 41.43 & 52.95 & 1.89 & Meandriforme & \\
\hline 2002 & 381.17 & 129.68 & 292.14 & 1856.87 & 439.16 & 1186.40 & 1375.56 & 484.25 & 863.87 & 100.02 & 38.47 & 67.66 & 2.35 & Meandriforme & \\
\hline 2002 & 358.50 & 129.31 & 259.31 & 1605.48 & 438.14 & 1041.57 & 1375.56 & 181.84 & 764.13 & 100.02 & 46.80 & 78.46 & 2.10 & Meandriforme & \multirow{10}{*}{ 2002-2011 } \\
\hline 2002 & 381.17 & 98.90 & 271.83 & 1371.93 & 464.86 & 924.11 & 1303.67 & 192.14 & 651.30 & 84.64 & 43.52 & 59.80 & 2.03 & Meandriforme & \\
\hline 2003 & 338.70 & 123.81 & 267.86 & 1371.93 & 672.49 & 1047.35 & 1305.36 & 336.36 & 736.51 & 86.03 & 45.80 & 69.48 & 1.94 & Meandriforme & \\
\hline 2004 & 363.94 & 129.05 & 287.38 & 1712.00 & 539.91 & 1261.54 & 1440.17 & 318.42 & 870.28 & 69.24 & 2303 & 54.37 & 1.90 & Meandriforme & \\
\hline 2004 & 363.40 & 132.70 & 284.85 & 1424.64 & 539.91 & 1179.77 & 1059.44 & 286.19 & 769.21 & 70.94 & 24.33 & 49.04 & 1.68 & Meandriforme & \\
\hline 2005 & 335.23 & 135.44 & 250.96 & 1470.36 & 362.21 & 1103.16 & 1071.14 & 282.72 & 795.37 & 107.17 & 54.41 & 75.13 & 1.71 & Meandriforme & \\
\hline 2006 & 312.06 & 121.31 & 268.71 & 1424.64 & 539.91 & 1179.77 & 1059.44 & 286.19 & 769.21 & 138.50 & 62.17 & 89.72 & 1.64 & Meandriforme & \\
\hline 2007 & 330.16 & 285.29 & 308.86 & 1334.56 & 871.00 & 1053.30 & 1079.60 & 606.29 & 814.84 & 156.94 & 68.73 & 94.98 & 1.50 & Meandriforme & \\
\hline 2008 & 371.31 & 295.02 & 333.17 & 1468.18 & 993.30 & 1230.74 & 1031.64 & 886.43 & 959.03 & 83.22 & 41.43 & 65.80 & 1.53 & Meandriforme & \\
\hline 2010 & 362.02 & 277.10 & 333.60 & 1480.08 & 1114.97 & 1351.43 & 1176.20 & 677.12 & 914.39 & 56.01 & 23.08 & 42.68 & 1.47 & Meandriforme & \\
\hline 2011 & 360.00 & & 360.00 & 1275.84 & & 1275.84 & 732.33 & & 732.33 & 96.41 & 39.23 & 61.97 & 1.31 & Sinuoso & \multirow{2}{*}{ 2011-2013 } \\
\hline 2013 & 412.53 & 201.71 & 307.12 & 1210.86 & 1041.64 & 1126.25 & 890.95 & 436.51 & 663.73 & 70.94 & 20.10 & 43.68 & 1.38 & Sinuoso & \\
\hline 2015 & 338.55 & 160.31 & 244.06 & 1338.32 & 659.32 & 1102.63 & 1105.64 & 378.36 & 663.71 & 76.24 & 34.41 & 59.77 & 1.54 & Meandriforme & \multirow{3}{*}{ 2013-2017 } \\
\hline 2016 & 341.69 & 139.84 & 244.86 & 1341.31 & 632.45 & 1000.58 & 1137.79 & 322.20 & 581.41 & 116.43 & 58.60 & 80.04 & 1.63 & Meandriforme & \\
\hline 2017 & 341.69 & 80.00 & 244.56 & 1224.83 & 297.31 & 875.18 & 1157.92 & 238.13 & 536.27 & 78.47 & 25.60 & 52.80 & 1.74 & Meandriforme & \\
\hline
\end{tabular}

compactas que disminuyen la infiltración. Por lo tanto, se incrementa la escorrentía y los procesos erosivos favorecidos por las pendientes. Se han observado procesos de erosión laminar y en surcos en las plantaciones, y cárcavas y barrancos en los desagües.

Desde 1975 hasta 2017 se han incorporado 774.61 ha a la actividad agrícola, en desmedro del bosque nativo, los cultivos de caña de azúcar disminuyeron en 726.43 ha y se incrementaron los cultivos de citrus (1102.59 ha), arándanos (329.90 ha) y la superficie ocupada por la población de río Seco (68.55 ha). La posición que ocupan en el relieve estos campos de cultivos, su cercanía a los cauces naturales y el mal manejo, son las razones por las que adquiere relevancia su influencia en el aporte de sedimentos a los cauces, fundamentalmente por la modificación del escurrimiento superficial. Ante estos cambios, el incremento de la frecuencia e intensidad de las precipitaciones a partir de 1970, favoreció un mayor aporte sostenido de sedimentos a los cauces, por eventos extremos más frecuentes y violentos. Estos eventos de lluvia se manifestaron sobre una cuenca que presenta una rápida respuesta ante una precipitación intensa, dado que ha alcanzado un alto desarrollo hidrológico (orden 6), y cuyos índices morfométricos muestran el predominio del escurrimiento superficial sobre la infiltración, con alta susceptibilidad a los procesos erosivos, torrencialidad moderadamente alta, bajo coeficiente de almacenamiento y alta probabilidad de crecientes, con elevadas pendientes de la zona montañosa en un sustrato de moderada permeabilidad secundaria (basamento ígneo-metamórfico) y con una intensa actividad antrópica que ha modificado paulatinamente la cobertura vegetal.

La influencia de la modificación de la cobertura en el incremento del escurrimiento superficial es manifestada, en este trabajo, tomando como referencia una cobertura hipotética de monte para toda el área de aporte en 1876, año 
en que se considera que comenzó la explotación de los bosques en Tucumán. Para ello se aplicó el Método de la Gurva Número (Natural Resources Conservation Service, 1986 y 2004), cuyos resultados constatan un aumento de $4.34 \mathrm{~mm}$ para una CPH II y de $8.84 \mathrm{~mm}$ para CPH III en el período 1876-2017, para un intensidad de precipitación de $75 \mathrm{~mm} / \mathrm{h}$, distribuida uniformemente en toda el área de aporte. Con estos resultados se infiere que los caudales erogados en dichas condiciones tienen capacidad suficiente para transportar los sedimentos desde la cuenca alta y erosionar las barrancas del cauce compuestas por limos, arenas y gravas. A esto debe sumarse la ubicación de la cuenca alta, lo que ya fue considerado por Busnelli y Horta (2014) en cuanto a su capacidad para concentrar mayor cantidad de precipitaciones, debido a que la humedad se condensa por ascenso orográfico entre los 850 y 1300 msnm. Es decir, la mayor pluviosidad se produce sobre la zona montañosa, en un sustrato de moderada permeabilidad y mayor frecuencia de cauces de orden 1 (1196 cauces), el 81\% del total de cauces de la subcuenca.
El número de corrientes de primer orden ha sido correlacionado con el pico de descarga de corrientes en el Appalachian Plateau por Morisawa (1962) y en Texas (Patton y Baker, 1976). En un estudio de los parámetros morfométricos relacionados a la descarga de las corrientes, el número de corrientes de primer orden fue la variable más significante correlacionada con la descarga de inundación para amplias regiones fisiográficas (Patton, 1988).

El proceso de formación de meandros en la llanura aluvial, período 1975-2017, tuvo su mayor progresión en 2002. La progresión de estos meandros hacia el norte se detuvo a consecuencia de que el cauce se alejó del eje de escurrimiento principal, disminuyendo su pendiente y su capacidad para conducir agua. Por ende, disminuyó su energía para erosionar y transportar sedimentos, produciéndose la deposición y el abandono del mismo. Shields y Abt (1989) expresaron que los meandros abandonados actúan como zonas de captación de sedimentos dentro de la llanura, registrando las facies sedimentarias de las sucesivas inundaciones desde el momento de abandono hasta el relleno completo. Numerosos rasgos tales como estrías,

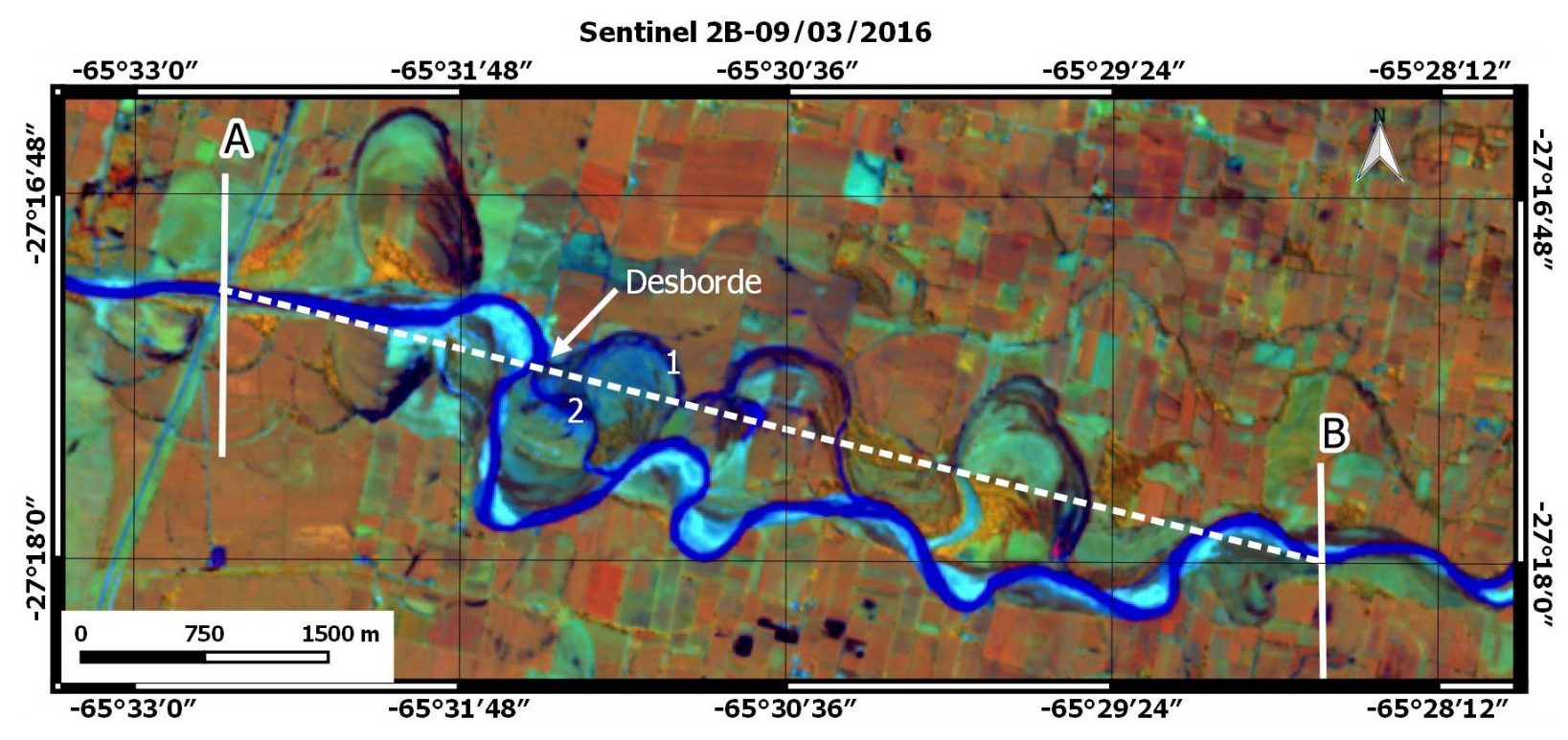

Figura 20 Imagen satelital Sentinel 2B de fecha 09 de marzo de 2016. La flecha indica el sitio de desborde de la corriente principal. 1. flujo encauzado en los arcos de los meandros abandonados, 2. flujo encauzado en un surco de desborde. 


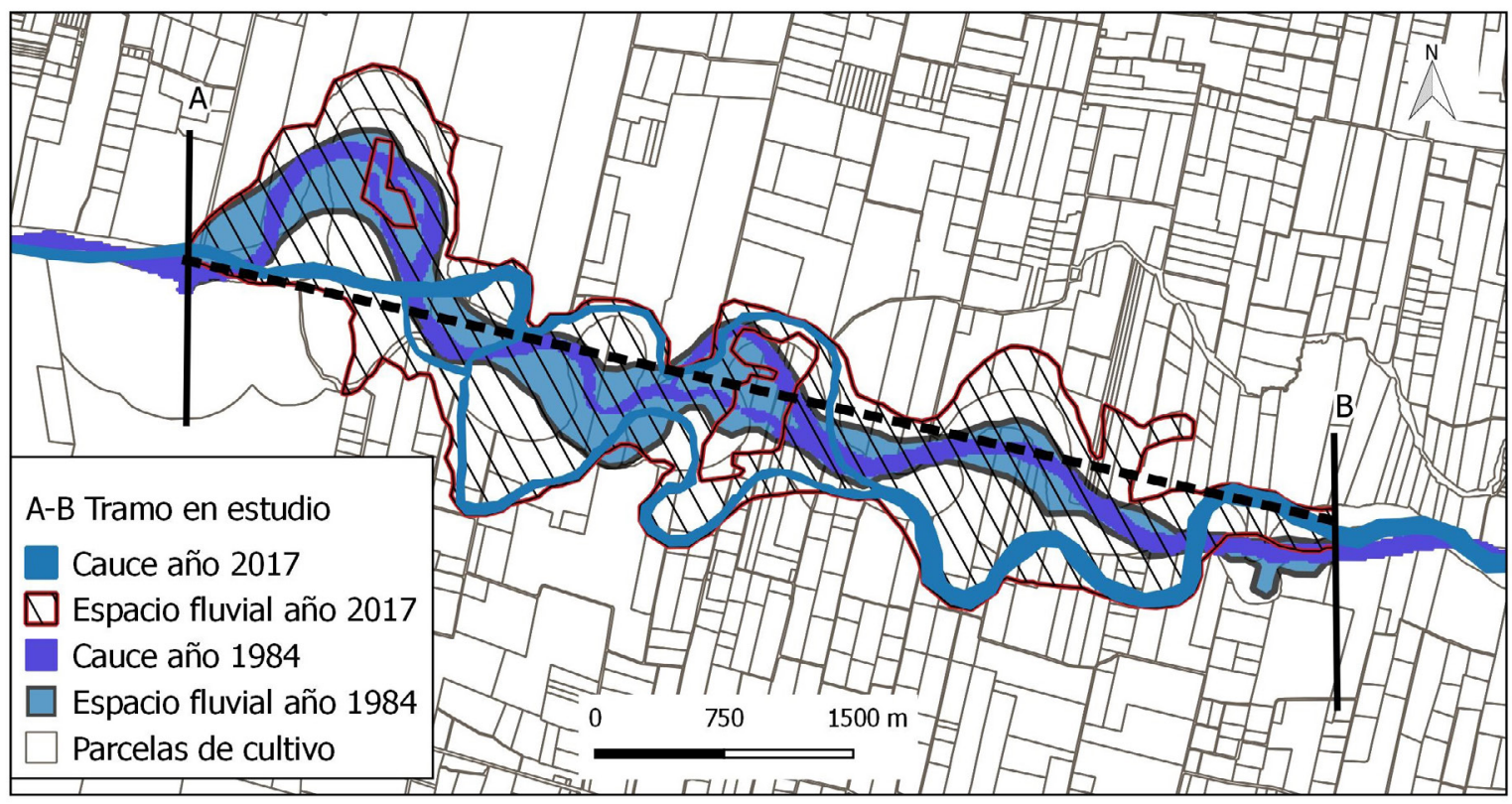

suelos hidromórficos y lagunas se observan en los lóbulos de los meandros abandonados de la margen izquierda, como expresión superficial de los depósitos de arenas y gravas fluviales.

Las corrientes debieron cortar los aluviones para labrar su nuevo cauce por rectificación o corte del meandro por desborde (chute cutoff). Este proceso, relacionado con fuertes crecientes y arrastre de material fino, arenas y gravas, fue acompañado por erosión retrocedente e incisión vertical del cauce. Posteriormente, la corriente tuvo mayor influencia sobre la margen derecha, con su máxima expresión en el año 2017.

Las figuras 15, 16 y la tabla 5 dan cuenta de cómo ha variado el cauce del río Seco desde 1972 hasta 2017. De 1972 a 2002 tuvo un notable crecimiento de la sinuosidad. A partir de 2002 hasta 2011 se sucedieron procesos de cortes de meandros que disminuyeron la sinuosidad y desde el año 2011 al 2017 comenzó a incrementarse nuevamente la sinuosidad conjuntamente con la migración del cauce hacia el sur.

Schumm (1977) consideró que cuando se produce un aumento simultáneo de caudal y carga de sedimentos, aumenta el ancho, la longitud de onda de los meandros y la relación ancho profundidad del canal, mientras que disminuye la sinuosidad. El gradiente y la profundidad pueden reaccionar en uno u otro sentido. En el caso del tramo analizado, y como se observa en la Figura 19, los cortes marcaron un punto de inflexión en la evolución de los mismos. Antes de 2002 las curvas son suaves; se observa también que el radio de curvatura no cambió notablemente, la longitud de onda tuvo una sensible disminución y la amplitud de onda se incrementó. Por el contrario, a partir de 2002, las curvas se muestran más quebradas, con notables variaciones en los parámetros analizados. Estas modificaciones impulsaron además la migración del cauce hacia el sur (Figura 16).

Siguiendo los postulados de Schumm (1977), es posible que la elevada carga sedimentaria y la energía de las corrientes se hayan manifestado con mayor intensidad en el período 2002-2011, lo que sumado a la baja pendiente del tramo analizado $(0.2 \%-2 \%)$ sean los principales factores que produjeron procesos de avulsión elevando el cauce, en muchos casos, hasta el nivel del terreno, produciendo desbordes. Bajo estas condiciones, el flujo excedente impulsa el proceso erosivo por erosión laminar sobre el terreno aguas arriba de la curva del meandro y por erosión retrocedente en la 
curva aguas abajo, labrando un nuevo cauce que produce el corte (chute cutoff). Las características de la planicie aluvial, como las diferencias locales en la topografía, la composición de los sedimentos y la vegetación, pueden alterar localmente el flujo de la corriente, promoviendo o inhibiendo la erosión (Constantine et al., 2010). En la llanura aluvial se encuentran canales abandonados, antiguos meandros y depresiones topográficas relacionadas al cauce actual, que actúan como vías preferenciales en las que se concentra el flujo excedente (Viero et al., 2018) lo que aumenta el poder de erosión sobre depósitos de sedimentos menos consolidados, favoreciendo así los procesos de chute cutoff.

El análisis de las imágenes Landsat evidencia los procesos de corte de meandros (chute cutoff). En el caso del corte del meandro M1 (Figura 18), fue producido entre febrero y noviembre de 2002. En la imagen de febrero se observa un surco de desborde. Por la forma de este rasgo superficial, sería parte de un antiguo cauce del río, el que solo es ocupado por la corriente durante las crecidas. En marzo el flujo principal labró una nueva vía preferencial de escurrimiento siguiendo la traza del surco y modificando sus márgenes por erosión lateral. Sin embargo, la curva del meandro mantuvo una cierta pendiente que favoreció la circulación de parte del escurrimiento. Finalmente, en noviembre se establece definitivamente la nueva vía de escurrimiento, con abandono del meandro.

Una secuencia similar se presentó en el meandro M3 (Figura 18), entre marzo y diciembre de 2004, con la diferencia de que existían una serie de surcos o canales abandonados que podrían encausar la corriente. Uno de ellos es el indicado como "antiguo cauce" en la imagen de marzo de 2004. Sin embargo, y como ocurrió en el caso del meandro M1, la corriente se encauzó en un surco ubicado aguas abajo de la curva del meandro, donde se presenta el mayor proceso erosivo por erosión lateral y donde impacta el flujo de las crecientes. En diciembre de 2004 se observa el abandono
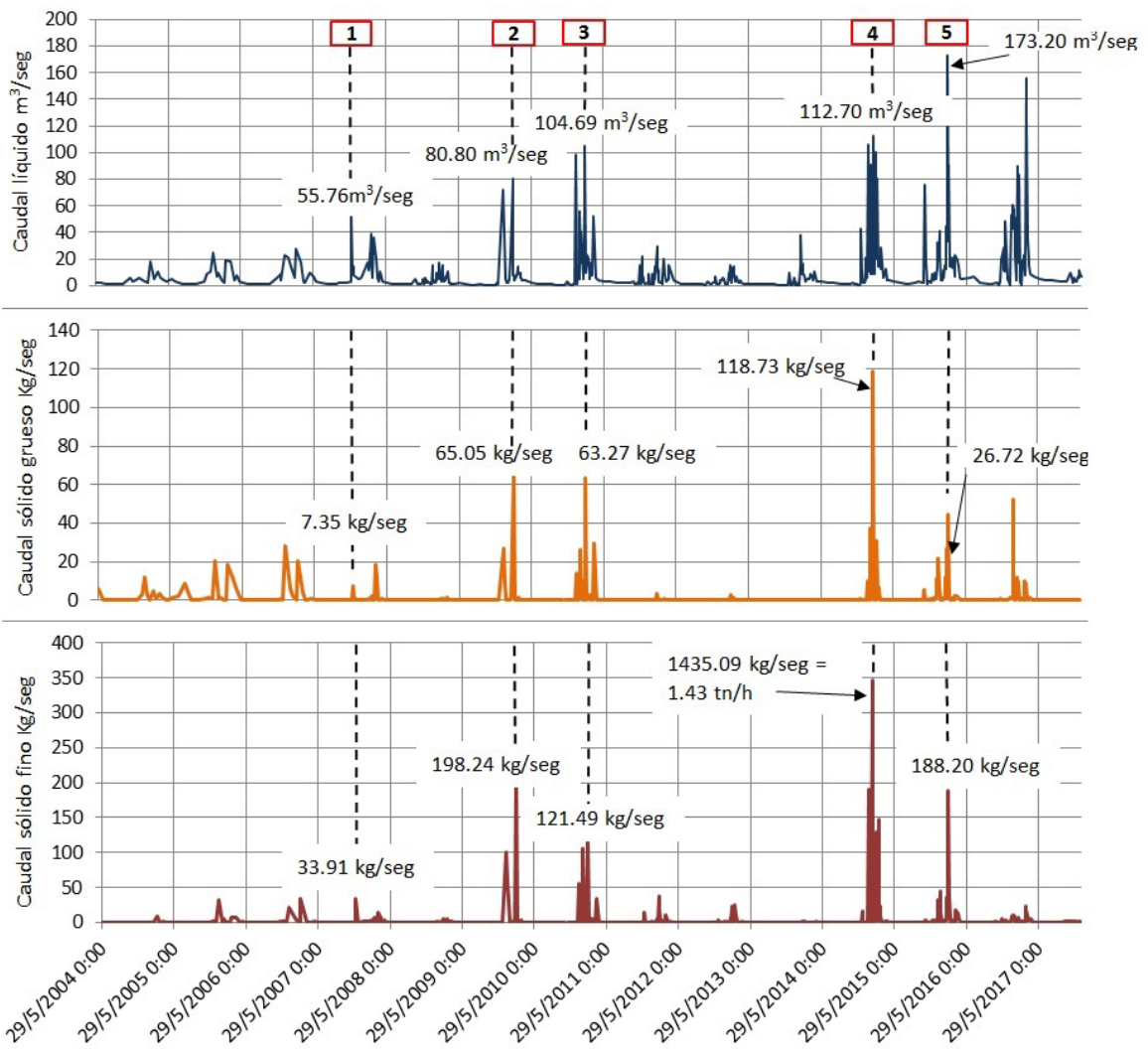

Figura 22 Comparación entre los hidrogramas de descarga líquido y sólidos (gruesos y finos) de la cuenca del río Seco. Referencia=fecha: $1=14 / 12 / 2007,2=25 / 02 / 2010,3=24 / 02 / 2011,4=16 / 02 / 2015$ y $5=25 / 02 / 2016$. 
parcial del meandro y el establecimiento del nuevo canal. En el caso del meandro M4 (Figura 17), el nuevo canal, o nueva vía de evacuación, se configuró entre el 31 de diciembre de 2006 y el 25 de febrero de 2007, mientras que el nuevo canal del meandro M5 (Figura 17) se formó entre el 18 de diciembre de 2010 y el 28 de febrero de 2011.

A diferencia de los ejemplos anteriores, el meandro M2 (Figura 18) fue producido por un corte por tangencia (neck cutoff), debido a que las curvas adyacentes se intersectaron por tangencia, entre marzo de 2002 y marzo de 2004, lo que formó un bucle abandonado (oxbow lake) (Hooke, 1995; Howard, 1996). Las características de este proceso de corte por tangencia y su ubicación aguas abajo de los meandros analizados y el tiempo transcurrido para que se produzca el corte, aproximadamente 2 años, podría estar indicando un cambio en la composición sedimentaria de las barrancas, las que estarían compuestas de sedimentos más cohesivos y de mayor resistencia a los procesos erosivos.

El análisis de las series de precipitaciones y de caudales da indicios de las causas que favorecieron estos procesos. Los meandros M1, M2 y M3 fueron relacionados a inundaciones provocadas por intensas precipitaciones en la alta cuenca, mientras que los procesos observados en los meandros M4 y M5 fueron relacionados con crecientes registradas en la Estación Ruta Nacional 157, ERN 157 en la Figura 6. En el caso del meandro M4 se observan claramente los surcos generados por desborde y erosión retrocedente, que ya son visibles en la imagen del 31 de diciembre de 2006. Por lo que para la conformación del nuevo canal no fueron necesarios elevados caudales.

Por el contrario, el corte del meandro M5 fue producido en una temporada de lluvias por fuertes crecientes, con caudales de 98 a 103 m3/seg. Los lapsos temporales en los cuales ocurrieron estas modificaciones ejemplifican lo expresado por Gay et al. (1998) e Iwasaki et al. (2016) en cuanto a que los cortes de meandros se forman con un solo flujo de inundación al principio o durante un solo evento.
Las intensas precipitaciones registradas posteriores al año 2011, como la febrero de 2016, incrementaron la sinuosidad del cauce por erosión lateral; no se observaron nuevos procesos de cortes de meandros (excepto durante las crecidas, pero que no conforman un canal definitivo que conduzca mayores volúmenes de escurrimiento) y se produjo la migración del cauce hacia el sur. Esta modificación del paisaje es una notable adaptación del sistema fluvial para contener los sedimentos que le son aportados por la alta cuenca, funcionando como zonas de captación, de acuerdo con Shields y Abt (1989).

En la temporada de aguas bajas, los sedimentos depositados por avulsión funcionan como diques. Las corrientes con baja energía se infiltran y ocupan antiguos cauces o meandros abandonados de la margen izquierda, con pendiente suficiente para permitir el flujo de la corriente y/o producir encharcamientos. Los sistemas fluviales son notablemente sensibles a los cambios del ambiente cuando se exceden ciertos umbrales, produciendo alteraciones en los cauces, como el analizado en el presente trabajo. Estas alteraciones de los cauces fluviales son indicadores hidrológicos del estado de degradación de sus áreas de aporte.

En ese sentido, en caso de manifestarse una tendencia a un cambio a condiciones más húmedas, con incremento de las precipitaciones en las áreas cumbrales, puede considerarse, a grandes rasgos, que los principales cambios se llevarán a cabo en la llanura aluvial.

\section{Conclusiones}

El tramo analizado del río Seco ha tenido importantes variaciones en la morfología del cauce, durante el lapso temporal 1972-2017, con notables cambios en la sinuosidad del cauce, producidos por procesos activos de dinámica fluvial.

La sinuosidad del cauce creció hasta 2002, disminuyó paulatinamente hasta 2011 , por procesos de cortes de meandros, y se incrementó nuevamente hasta 2017. El proceso de corte de meandros 
más frecuente fue el de corte por desborde (chute cutoff), causados por crecientes producidas en la alta cuenca, debido a precipitaciones intensas.

Los sedimentos fluvio-aluviales de las márgenes, presencia de antiguos cauces y depresiones anegables y la variabilidad sedimentaria de los interfluvios y llanura aluvial, favorecieron los procesos de chute cutoff.

Se observó un solo caso de corte por tangencia (neck cutoff). Su ubicación, al final del tramo en estudio, podría indicar un cambio en la litología de las barrancas, compuestas por sedimentos de mayor resistencia a los procesos erosivos de naturaleza hídrica.

Un hidrograma de descarga de caudal líquido permitió relacionar los procesos de corte en el canal con los caudales entregados por la cuenca. Como consecuencia de estos procesos el cauce tuvo una migración hacia el sur por erosión lateral sobre las barrancas del río, produciendo con ello la pérdida de 370.68 ha de suelos productivos. El volumen de sedimentos erosionados de las barrancas y transportado por la corriente fue de $7.41 \mathrm{hm}^{3}$.

Los procesos de chute cutoff y neck cutoff fueron incentivados por la extracción de la cobertura boscosa y la ampliación de las superficies con cultivos y urbana en la cuenca media-alta, lo que disminuyó la infiltración de los suelos e incrementó el escurrimiento superficial y los procesos erosivos.

La escorrentía producida como consecuencia del cambio de uso de los suelos tuvo un notable incremento en el lapso temporal 1876-1975, principalmente por la eliminación parcial de la cobertura boscosa para favorecer los cultivos de caña de azúcar. Durante el período 1975-2017 hubo una atenuación en los valores de escurrimiento. El incremento de las precipitaciones a partir de 1970 generó un mayor aporte sostenido de caudales líquidos y sólidos a los cauces, incentivando los procesos erosivos. Estas condiciones favorecieron la rápida respuesta del área de aporte ante un evento de lluvia, con torrencialidad moderadamente alta y alta probabilidad de crecientes.

El sistema de meandros del río Seco refleja la degradación de su área de aporte y representa la situación de diversas cuencas del Noroeste Argentino, en las cuales el incremento de la intensidad y frecuencia de las precipitaciones en los últimos años han generado situaciones críticas cuyos efectos son más evidentes en las áreas bajas.

\section{Agradecimientos}

A la Fundación Miguel Lillo por haber brindado los fondos para la realización de este trabajo. Además agradecemos a los árbitros, por la lectura crítica del manuscrito y correcciones que contribuyeron al enriquecimiento del mismo. $\mathrm{Al}$ igual a la Dra. Laura Perucca por la revisión y sugerencias aportadas para la mejora de este trabajo y al Dr. Pablo Grosse por sus recomendaciones para la realización del resumen en inglés.

\section{Referencias}

Aplicativo Google Earth, 2018, disponible en https://www.google.com/intl/es-419_ALL/ earth/versions/, consultado 10 de octubre de 2019.

Arcuri, C. B., 1995, Chapter 3: Theory and Concepts of Flood Hazard Assessment, in Flood Hazard Assessment and ZonationMedinas River (Tucumán-Argentina): Enschede, Holland, Master of Sciences, ITC (International Institute for Geo-Informatics and Earth Observation), 26-64.

Bergsma, E., 1982, Aerial photo-interpretation for soil erosion and conservation surveys, lectures notes, part. II -III: Enschede, Holanda, ITC International Institute for Geo-Informatics and Earth Observation), 138-140.

Bianchi, A. R., Yañez, G.E., Acuña, L.R., 2005, Base de datos mensuales de precipitaciones del noroeste argentino, Proyecto Riesgo Agropecuario: Secretaría de Agricultura, Ganadería, Pesca y Alimentación, Instituto Nacionalde Tecnología Agropecuaria(INTA), Centro regional Salta-Jujuy, disponible en: 
https://inta.gob.ar/documentos/isohietasanuales-del-noroeste-argentino, consultado en marzo de 2019.

Bogoni, M., Putti, M., Lanzoni, S., 2017, Modelling meander morphodynamics over self-formed heterogeneous floodplains: Water Resources Research, 53(6), 5137-5157. https://doi. org/10.1002/2017wr020726

Busnelli, J., 2009, Evolución Histórica, Situación Actual y Perspectivas Futuras del Riesgo de Inundación en la cuenca del Río Gastona. Tucumán. Argentina: San Miguel de Tucumán, Facultad de Ciencias Naturales e Instituto Miguel Lillo. Universidad Nacional de Tucumán, tesis doctoral, $629 \mathrm{p}$.

Busnelli, J. y Horta L. R., 2014, Morfometría de cuencas de montañas y metamorfosis fluvial, Tucumán: Revista de la Asociación Geológica Argentina, 71 (1), 11 - 20

Caminos, R., 1979, Las Sierras Pampeanas Noroccidentales de Salta, Tucumán, Catamarca, La Rioja y San Juan, en Actas $2^{\circ}$ Simposio Geológico Regional Argentino: Córdoba, 1, 225-291.

Camporeale, C., Perona, P., Porporato, A., Ridolfi, L., 2005, On the long-term behavior of meandering rivers: Water Resources Research, 41(12), W12403. https://doi. org/10.1029/2005wr004109

Castañeda, M. y Barros, V.R., 1994, Las tendencias de la precipitación en el Cono sur de América al Este de los Andes: Meteorológica, 19, 23-32.

Constantine, J.A., McLean, S.R., Dunne, T., 2010, A mechanism of chute cutoff along large meandering rivers with uniform floodplain topography: Geological Society of America Bulletin, 122(5-6), 855-869. https://doi. org/10.1130/b26560.1

Diario La Gaceta de Tucumán, 2012, El ferrocarril cambió la industria azucarera (en línea): Tucumán, Argentina, La Gaceta, publicado el 28 de Diciembre de 2012, disponible en https://www. lagaceta.com.ar/nota/527005/sociedad/ ferrocarril-cambio-industria-azucarera.html, consultado en febrero de 2019.

Díaz Gómez, R., Gaspari, F. J., Georgieff, S.M., 2017, Aspectos morfométricos de cuencas subtropicales del Noroeste de Argentina: Acta Geológica Lilloana, 29 (1), 3-19.

Dury G.H. (1965). Theoretical implications of underfit streams: USGS Numbered Series, Professional Paper, 452 C, 53p.

Earth Observing System(EOS) Land Viewer, 2018, disponible en: https:/ / eos.com/ consultado de noviembre de 2018 a marzo de 2019.

Estación Experimental Agroindustrial Obispo Colombres (EEAOC), 2017, Área cosechable y producción de caña de azúcar y azúcar para la zafra 2017 en Tucumán (en línea), Boletín $\mathrm{N}^{\circ}$ 138, disponible en: http:// www.eeaoc.org.ar/upload/publicaciones/ archivos/709/20170626161048000000.pdf, consultado en marzo de 2019.

Estación Experimental Agroindustrial Obispo Colombres (EEAOC), 2018, Sección Agrometeorología (en línea), Tucumán, Argentina, disponible en: http://www.eeaoc. org.ar/agromet/index.php, consultado de Marzo a abril de 2018.

Fondo Internacional de Desarrollo Agrícola (FIDA), 2011, La problemática de la tierra en Argentina. Conflictos y dinámicas de uso, tenencia y concentración: Argentina, Ministerio de Agricultura, Ganadería y Pesca, Presidencia de la Nación, disponible en <http://www.eeaoc.org.ar/agromet/>, consultado en abril de 2019.

Frascati, A. , Lanzoni, S., 2010, Long-term river meandering as a part of chaotic dynamics? A contribution from mathematical modeling: Earth Surface Processes and Landforms, 35(7), 791-802. https://doi.org/10.1002/ esp. 1974

García Lorenzo, R., Conesa García, C., Pérez Cutillas, P., 2015, Análisis espacial de la geometríademeandrosabandonadosrecientes en la Vega Media del Segura (Murcia), en de la Riva, J., Ibarra, P., Montorio, R., Rodrigues, 
M. (eds.), Análisis espacial y representación geográfica: innovación y aplicación: España, Universidad de Zaragoza-AGE, 1609-1617.

Gay, G.R., Gay, H.H., Gay, W.H., Martinson, H.A., Meade, R.H., Moody, J.A., 1998, Evolution of cutoffs across meander neck in Powder River, Montana, USA: Earth Surface Processes and Landforms, 23(7), 651-662.https://doi.org/10.1002/ (sici) 1096-9837(199807)23:7<651::aidesp891>3.0.co;2-v

González Bonorino, F., 1951, Descripción Geológica de la hoja 12c (Aconquija), Catamarca-Tucumán: Buenos Aires, Argentina, Dirección Nacional de Minería, Boletín 75, 51p.

Grenfell, M., Aalto, R., Nicholas, A., 2012, Chute channel dynamics in large, sand-bed meandering rivers: Earth Surface Processes and Landforms, 37(3), 315-331. https://doi. org/10.1002/esp.2257

Guido, E. y Busnelli, M., 1993, Criterios morfométricos para la evaluación de la torrencialidad de una cuenca hídrica (Río Las Cañas, Catamarca), en $12^{\circ}$ Congreso Geológico Argentino y $2^{\circ}$ Congreso de Exploración de Hidrocarburos, Mendoza, Argentina, Asociación Geológica Argentina, 4, 112-122.

Hooke, J.M., 1995, River channel adjustment to meander cutoffs on the River Bollin and River Dane, north-west England: Geomorphology, 14(3), 235-253. https:// doi.org/10.1016/0169-555x(95)00110-q

Hooke, J.M., 2007, Spatial variability mechanisms and propagation of change in an active meandering river: Geomorphology, 84(34), 277-296. https://doi.org/10.1016/j. geomorph.2006.06.005

Horton, R., 1945, Erosional development of streams andtheirdrainage basins:Hydrologicalapproach to quantitative morphology: Geological Society American Bulletin 56(3), 275-370. https://doi. org/10.1130/0016-7606(1945)56[275:edosat 2 $.0 . \operatorname{co} ; 2$
Howard, A.D., 1996, Modeling channel evolution and floodplain morphology, in Anderson, M.G., Walling, D.E., Bates, P.D. (eds.), Floodplain Processes, Chichester, UK, Wiley, 15-65.

Howard, A., Knutson, T.R., 1984, Sufficient conditions for river meandering: A simulation approach: Water Resources Research, 20(11), 1659-1667. https://doi.org/10.1029/ wr020i011p01659

Ielpi, A., Ghinassi, M., 2014, Planform architecture, stratigraphic signature and morphodynamics of an exhumed Jurassic meander plain (Scalby Formation, Yorkshire, UK): Sedimentology, 61(7), 1923-1960. https://doi.org/10.1111/sed.12122

Instituto Nacional de Tecnología Agropecuaria (INTA). Mapa de Suelos de la República Argentina. Escala 1:500.000, GeoINTA, disponible en http://www.geointa.inta.gob.ar/ descargas/, consultado 24 de junio de 2018.

Iwasaki, T., Shimizu, Y., Kimura, I., 2016, Numerical simulation of bar and bank erosion in a vegetated floodplain: A case study in the Otofuke River: Advances in Water Resources, 93, 118-134. https://doi. org/10.1016/j.advwatres.2015.02.001

Leopold, L.B., Wolman, M.G., 1957, River channel patterns: braided, meandering and straight: U.S. Geological Survey Professional Paper 282-B, 50p.

Leopold, L.B., Wolman, M.G., 1960, River meanders: Geological Society of America Bulletin, 71(6), 769794. https://doi.org/10.1130/00167606(1960)7 1 [769:rm]2.0.co;2

Leopold, L.B., Wolman, M.G., Miller, S.P., 1964, Fluvial Processes in Geomorphology: San Francisco, Freeman and Co., 522 p.

Levene, R., 1939, Historia de la Nación Argentina, desde los orígenes hasta la organización definitiva en 1862: Buenos Aires, El Ateneo, Academia Nacional de la Historia, II, 722 p. Malizia S., García Moritán M., Brown A.D., 2014, Bitácora de la ruta del azúcar, 200 años promoviendo el desarrollo regional: 
Tucumán, Argentina, Ediciones del Subtrópico, 85 p.

Miall, A.D., 1977, Fluvial Sedimentology: Calgary, Canadian Society of Petroleum Geologists, Memoir 5, 859 p.

Microsoft Excel, 2013, Planilla de cálculo (CDROM): Redmond, Washington, Microsoft Corporation, 1 CD-ROM.

Minetti, J.L., Neder, R.A., Suárez, L.C., Minetti de Costilla, A.M., 1979, Balance Hidrológico de la Cuenca y Subcuencas del Río Salí: Tucumán, Argentina, Estación Experimental Agroindustrial Obispo Colombres, Publicación Miscelánea $\mathrm{N}^{\circ}$ 64, 53p.

Molina, Ada L., 1988, Geología e hidrogeología de la cuenca del río Seco y del arroyo del Estero (Provincia de Tucumán): Tucumán, Argentina, Facultad de Ciencias Naturales e Instituto Miguel Lillo, Seminario, 155 p.

Morais, E.S., Rocha, P.C., Hooke, J., 2016, Spatiotemporal variations in channel changes caused by cumulative factors in a meandering river: The lower Peixe River, Brazil: Geomorphology, 273, 348-360. https://doi. org/10.1016/j.geomorph.2016.07.026

Morisawa, M.E., 1962. Quantitative geomorphology of some watersheds in the Appalachian Plateau: Geological Society of American Bulletin 73(9), 1025-1046.https:// doi.org/10.1130/0016-7606(1962)73[1025:qg oswi]2.0.co;2

Nanson, G.C., Croke, J.C., 1992, A genetic classification of floodplains: Geomorphology, 4 (6), 459-486. https://doi. org/10.1016/0169-555x(92)90039-q

Natural Resources Conservation Service (NRCS), 1986, Urban Hydrology for Small Watersheds: Washington, D.C., United States Department of Agriculture, Technical Release 55, 164 p., disponible en: https://www.nrcs. usda.gov/Internet/FSE_DOCUMENTS/ stelprdb1044171.pdf, consultado en abril de 2019.

Natural Resources Conservation Service (NRCS), 2004, Estimation of direct runoff from storm rainfall, in NRCS National Enginering Handbook, Part 630-Hidrology: Washington, D.C., United States Department of Agriculture, 10.1-10.22, disponible in: http://policy.nrcs.usda.gov/scripts/lpsiis. dll/H/H_210_630_10-pdf>, consultado en abril de 2019 .

Ollero, A., 2007, Territorio fluvial. Diagnóstico y propuesta para la gestión ambiental y de riesgos en el Ebro y los cursos bajos de sus afluentes. Bakeaz y Fundación Nueva Cultura del Agua, 255 p., Bilbao.

Ollero, A., Ballarín, D., Díaz, E., Mora, D., Sanchez, M., Acín, V., González de Matauco, A., Echeverría, M.T., Granado, D., Abisate, A., Sanchez, L., Sanchez, N., 2007, Un índice hidrogeomorfológico (IHG) para la evaluación del estado ecológico de sistemas fluviales: geographicalia (2007), 52, 113-141. https: / / pdfs.semanticscholar.org/b7bc/ f65049e80c85400075991cc3e579e4d9dacd. pdf

Patton, P.G., 1988, Drainage Basin Morphometry and Floods, in Baker, V., Kochel, R., Patton, P. (eds.), Flood Geomorphology: New York, Wiley, 51-64.

Patton, P.C., Baker, V.R., 1976, Morphometry and floods in small drainage basins subject to diverse hydrogeomorphic controls: Water Resources Research, 12(5), 941-952. https:// doi.org/10.1029/wr012i005p00941.

Puchulu, M.E. y Fernández, D., 2014, Características y distribución espacial de los suelos de la provincia de Tucumán, en Moyano, S., Puchulu, M.E., Fernández, D., Aceñolaza, G., Vides, M.E., Nieva, S. (eds.), Geología de Tucumán: Tucumán, Colegio de Graduados en Ciencias Geológicas de Tucumán, 240-256.

Qgis 2.18.27 with Grass 7.4.2, 2016, Sistema de información geográfica de código libre: Boston, USA, Open Source Geospatial Foundation(OSGeo), disponible en: https:// gis.stackexchange.com/questions/288507/ grass-7-4-1-in-qgis-2-18 
Rassmuss, I., 1918, La Sierra de Aconquija, en Primera Reunión Nacional de la Sociedad Argentina de Giencias Naturales: Buenos Aires, Argentina, Physis, 47-69.

Sala, M. y Gay, R., 1981, Algunos datos morfométricas de la cuenca del Isábena: Notes de Geografía Física, 4, 41 - 65.

Sayago, J.M., 1992, El deterioro ambiental en el noroeste argentino: Estudios Geográficos, 53 (208), 543-567.

Sayago,J.y Cuenya, P. 1990. El deterioro del paisaje en la cadena del Aconquija y su influencia en la modificación de los diseños fluviales en la llanura tucumana, en Actas $14^{\circ}$ Congreso Nacional del Agua: Córdoba, Argentina, 2, 498-515.

Sayago J.M. y Toledo M.A., 1996, Rainfall increase (1970-90) and morphodynamic changes in the northwestern subtropical region of Argentina: an aproximation to the future climatic change effects, in Geowissenschaftliches LateinamerikaKolloquium: Hamburgo, Alemania, Terra Nostra, 126.

Sayago, J.M., Collantes M.M., Toledo M.A., 1998a, Geomorfología, en Gianfrancisco, M., Puchulu, M.E., Durango de Cabrera, J., Aceñolaza, G. (eds.), Geología de Tucumán: Tucumán, Colegio de Graduados en Ciencias Geológicas de Tucumán, 241-258.

Sayago, J.M., Neder L., Puchulu, M.E., 1998b, Suelos, en Gianfrancisco, M., Puchulu, M.E., Durango de Cabrera, J., Aceñolaza, G. (eds.), Geología de Tucumán: Tucumán, Colegio de Graduados en Ciencias Geológicas de Tucumán, 275-284.

Schumm, S. A., 1971, Fluvial geomorphology: Channeladjustmentandrivermetamorphosis, in Shen, H. W. (ed.), River mechanics, Volume 1: Fort Collins, Colorado, H. W. Shen, 5-1-5-22.

Schumm, S. A., 1977, The Fluvial System: New York, Willey, $333 \mathrm{pp}$.

Schwendel, A.C., Nicholas, A.P., Aalto, R.E., Sambrook Smith, G. H., Buckley, S., 2015,
Interaction between meander dynamics and floodplain heterogeneity in a large tropical sand-bed river: The Rio Beni, Bolivian Amazon: Earth Surface Processes and Landforms, 40(15), 2026-2040. https://doi. org/10.1002/esp.3777

Schwenk, J., Foufoula-Georgiou, E., 2016, Meander cutoffs nonlocally accelerate upstream and downstream migration and channel widening: Geophysical Research Letter, 43(24), 12437-12445. https://doi. org/10.1002/2016gl071670

Secretaría de Infraestructura y Política Hídrica de la Nación, 2018, Base de datos hidrológica integrada (en línea), Argentina, disponible en https://www.argentina.gob.ar/interior/ secretaria-de-infraestructura-y-politicahidrica/base-de-datos-hidrologicaintegrada>, consultado de Enero a Febrero de 2019

Shields, F.D., Abt, S., 1989, Sediment deposition in cutoff meander bends and implications for effective management: Regulated Rivers Research \& Management, 4(4), 381-396. https://doi.org/10.1002/rrr.3450040406

Semi-Automatic Classification Plugin (SCP) de Qgis 2.18.27 with Grass 7.4.2. en linea: disponible en https://qgis.org/en/site/.

SRTM1S28W066V3, Shuttle Radar Topography Misión. (2014). en línea: Disponible en https://earthexplorer.usgs.gov/. Consultado en febrero de 2018.

Strahler, A., 1964, Quantitative geomorphology of drainage basins and channel networks, in Chow, V.T. (ed.), Handbook of applied hidrology: New York, McGraw Hill, 39-73.

Strahler, A., 1974, Geografía física: Barcelona, España, Ediciones Omega, S.A., 765 pp.

Toledo, M.A., Fernández, R., Sayago, J.M., 2001, El embalse de Río Hondo como geoindicador del creciente deterioro ambiental en sus cuencas de aporte, en Actas $3^{\text {a }}$ Reunión Nacional y $1^{\text {a }}$ del Mercosur sobre Geología Ambiental y Ordenación del Territorio: Mar del Plata, Argentina, CD-ROM, 11 pp. 
Toonen, W.H.J., Kleinhans, M.G., Cohen, K.M., 2012, Sedimentary architecture of abandoned channel fills. Earth Surface Processes and Landforms, 37(4), 459-472. https://doi.org/10.1002/esp.3189

Torres Bruchmann, E., 1978, Las Clasificaciones climáticas de Koppen y Thorntwaite: Tucumán, Argentina, Facultad de Agronomía y Zootécnia, UNT, Serie Didáctica $N^{\circ}$ 48, 27 p.

United States Department of Agriculture (USDA), 1978, Predicting Rainfall Erosion Losses - A guide to conservation planning, in Agricultural Handbook $\mathrm{N}^{\circ}$ 282: Washington, D.C., United States Department of Agriculture, $67 \mathrm{p}$.

Van de Lageweg, W.I., van Dijk, W.M., Baar, A.W., Rutten, J., Kleinhans, M.G., 2014, Bank pull or bar push: What drives scroll-bar formation in meandering rivers?: Geology, 42(4), 319-322. https://doi.org/10.1130/ g35192.1

Van de Lageweg, W.I., Schuurman, F., Cohen, K.M., van Dijk, W.M., Shimizu, Y., Kleinhans, M.G., 2016, Preservation of meandering river channels in uniformly aggrading channel belts: Sedimentology, 63(3), 586-608. https://doi.org/10.1111/ sed. 12229
Van Dijk, W.M., Schuurman, F., Van de Lageweg, W.I., Kleinhans, M.G., 2014, Bifurcation instability and chute cutoff development in meandering gravel-bed rivers: Geomorphology, 213, 277-291. https://doi. org/10.1016/j.geomorph.2014.01.018

Viero, D., Lopez Dubon, S., Lanzoni, S.,2018, Chapter: 8, Chute cutoffs in meandering rivers: formative mechanisms and hydrodynamic forcing, in Massimiliano Ghinassi Luca Colombera Nigel P. Mountney Arnold Jan H. Reesink Mark Bateman (ed.), Fluvial Meanders and Their Sedimentary Products in the Rock Record, John Wiley \& Sons. 201-229. https:// doi.org/10.1002/9781119424437.ch8

Verstappen, H., 1983, Applied Geomorphology: Geomorphological Surveys for Environmental Development: New York, Elsevier, 437 p.

Werritty, A., 1997, Short-term changes in channel stability, in Thorne, G.R., Hey, R.D., Newson, M.D. (eds.), Applied fluvial geomorphology for river engineering and management, Chichester, UK, Wiley, 47-65.

Zinger,J.A., Rhoads, B.L., Best,J.L., 201 1, Extreme sediment pulses generated by bend cutoffs along a large meandering river: Nature Geoscience, 4(10), 675-678. https://doi. org/10.1038/ngeo1260 